\title{
Psycho-Oncology: A Bibliometric Review of the 100 Most-Cited Articles
}

\author{
Susan Fox ${ }^{1, *}$, Julie Lynch ${ }^{1,2}$, Paul D'Alton ${ }^{1,2}$ and Alan Carr ${ }^{1}$ \\ 1 School of Psychology, University College Dublin, D04 V1W8 Dublin, Ireland; julie.lynch@ucdconnect.ie (J.L.); \\ paul.dalton@ucd.ie (P.D.); alan.carr@ucd.ie (A.C.) \\ 2 St Vincent's University Hospital, D04 T6F4 Dublin, Ireland \\ * Correspondence: susan.fox.1@ucdconnect.ie
}

Citation: Fox, S.; Lynch, J.; D'Alton, P.; Carr, A. Psycho-Oncology: A Bibliometric Review of the 100 Most-Cited Articles. Healthcare 2021, 9, 1008. https://doi.org/10.3390/ healthcare 9081008

Academic Editor: Joaquim Carreras

Received: 17 May 2021

Accepted: 9 July 2021

Published: 6 August 2021

Publisher's Note: MDPI stays neutral with regard to jurisdictional claims in published maps and institutional affiliations.

Copyright: (c) 2021 by the authors. Licensee MDPI, Basel, Switzerland. This article is an open access article distributed under the terms and conditions of the Creative Commons Attribution (CC BY) license (https:// creativecommons.org/licenses/by/ $4.0 /)$.

\begin{abstract}
Background: A bibliometric review of psycho-oncology research is overdue. (2) Methods: The 100 most-cited journal articles were compiled and ranked according to Scopus. (3) Results: The total citation count for the results ranged from 488-8509 (Mean =940.27; $S D=1015.69$ ). A significant correlation was found between years since publication and number of citations $(p=0.039)$. The majority of research originated from the United States $(66 \%)$. The vast majority of research publications were original articles $(80 \%)$. Observational research study designs represented the majority of studies (37\%). Mixed cancer population research studies represented the largest cancer research population (36\%). Positive psychology topics represented the most prolific proportion of studies (30\%). Findings were reported in line with PRISMA-ScR guidelines. (4) Conclusions: This analysis offers a comprehensive account of seminal journal articles in psycho-oncology, identifying landmark contributions and areas for future research developments within the field, namely highlighting a need for more RCT studies. This analysis serves as an educational tool for interdisciplinary researchers and clinicians to support compassionate cancer care.
\end{abstract}

Keywords: cancer; bibliometrics; psycho-oncology; multidisciplinary; oncology; review

\section{Introduction}

Psycho-oncology is a collaborative, cross-disciplinary subspecialty of oncology with domains in the psychological, social, behavioural, and ethical aspects of cancer in clinical care $[1,2]$. The discipline provides clinical and research material about issues clinically relevant to health professionals who provide psychosocial services to cancer patients, their families, and their caregivers [3]. The foundations of the field first came into existence in the 1970s [1], the evolution of which has previously been detailed by the founder of the field, Dr Jimmie Holland [1,3].

Overtime a large body of literature has been published comprising a wide range of relevant research and clinical themes. A previous review of this wealth of literature by Greer outlines the important need to "close the yawning gap between current knowledge and therapeutic skills on the one hand and actual clinical care of cancer patients on the other" [4]. As the discipline approaches fifty years since formal foundation, a bibliometric review of the literature is warranted to aid the synthesis and implementation of the evidence base.

Citation count is an important metric in understanding the significance of a research contribution to a research field [5-7]. Situational analyses which identify research that has exerted significant citation influence offers researchers and clinicians an introduction to seminal research publications. It can be argued that the most-cited publications of a research field theoretically contribute the most to the respective field [8-11]. Notably, the approach has proved useful in practice-driven research funding decision-making by offering objective and reliable bibliometric quantitative analysis of grant productivity $[8,12]$. Bibliometric analyses with the aid of bibliographic electronic databases offer a systematic overview of peer-reviewed research in a range of disciplines and research 
fields $[13,14]$. Neurosciences have widely adopted the methodology to identify seminal research and contributors [15-22]. The use of bibliometric methodologies is emerging in cancer care [12,23-29]. However, to date, no known research has identified the highest-cited articles in psycho-oncology. Therefore, the aim of this study was to identify and describe the characteristics of seminal journal articles that have contributed to the development of the field of psycho-oncology. Given the extensive remit of the multidisciplinary field of psycho-oncology, a bibliometric review of the literature may prove a helpful introduction for researchers and clinicians working in cancer care.

\section{Materials and Methods}

\subsection{Study Design}

This article describes a citation analysis of journal articles in the field of psychooncology pertaining to the guidance of clinical practice and research. A review of the 100 most-cited papers is consistent with the methodological approach to bibliometric reviews in health research $[13,14,16,17,30-33]$. A review protocol was developed to support the study's objectives, search strategy, inclusion/exclusion criteria and risk of bias assessment. No deviations from the protocol were made.

\subsection{Search Strategy and Study Selection}

Publications pertaining to "psychosocial oncology" or "psycho-oncology" and psychological processes relating to cancer were identified. The search strategy was informed by the keywords and terms constructed by key journals in the field [2].

A time limit of publications from 1970 to 2020 was imposed on the searches, as the field of psycho-oncology was formally founded in the mid-1970s [1]. Searches were limited to the English language due to resource limitations (see Supplementary Material for detailed search strategy). The list of the top 100 cited articles was compiled and ranked according to the outputs from the Scopus database search in March 2020. Scopus was selected as the primary database because it provides access to more journals (approximately 34,346 peer-reviewed journals) than other widely used electronic databases, such as Web of Science (approximately 24,748 peer-reviewed journals) [34]. Key to database selection, Scopus provides tools for citation overview, allowing for bibliometric ranking of credited citations. Furthermore, several key psychosocial-oncology journals are indexed within Scopus. Inclusion of one electronic database is standard practice in bibliometric analyses $[14,16,17,30,31,33]$. Results retrieved from Scopus were sorted using the sorting option "times cited-highest to lowest." Scopus outputs were then exported to Covidence, an electronic primary screening and data extraction tool, which has been recommended as best practice in rigorous review methodology data charting [35-37]. Duplicates were removed. Two reviewers (S.F. and J.L.) independently applied the inclusion and exclusion criteria to screen each title and abstract using the Covidence platform. Disagreements between the two reviewers were resolved through a further detailed review of the article(s) in question, and discussion until consensus was reached. An equivalent process of review was conducted for the full-text screening phase. Cohen's $\mathrm{k}$ indicated almost perfect interrater reliability ( $\kappa=0.97,98.87 \%$ of agreement).

\subsection{Eligibility Criteria}

Eligibility criteria were bound to the remit outlined in key definitions of psychooncology $[1,2,38]$. Journal articles were eligible for inclusion if their major focus addressed the psychological, social, behavioural, ethical, and systemic dimensions of cancer (including stable and modifiable confounding and interacting factors); specifically, the psychological responses of patients to cancer at all stages of the disease, and that of their families and caregivers including their health professionals; and the factors that may influence the disease process [1]. Given the intrinsic multidisciplinary nature of psycho-oncology, journal articles from a range of disciplines were eligible for inclusion, where the primary focus explored subjects within the defined remit of psycho-oncology. Eligibility criteria were 
extended to counselling, education, epidemiology, health advocacy, neurology, nursing, nutrition, palliative care, physical therapy, psychiatry, psychology, public health, social work, sociology, and oncology specialities [2]. Journal articles published in the English language were eligible for inclusion. No restrictions were placed on the type of research model, article type (e.g., research article, review, conference proceedings, editorial, letter, etc.).

Studies were ineligible for inclusion if they were the following:

1. Journal articles with primarily medical foci despite the inclusion of brief quality of life measures;

2. Journal articles which described mixed patient populations beyond oncology; or

3. Did not have psycho-oncology research or practice as key foci.

\subsection{Data Extraction}

Data were extracted independently by the two reviewers. Information was extracted on the following variables: (1) title; (2) authorship and publication year; (3) country of publication and first author's affiliation at the time of publication; (4) journal; (5) article type (e.g., intervention, systematic review); (6) article global subject (e.g., cancer prevention, psychoneuroimmunology or post-traumatic growth); (7) number of citations; (8) and citation rank. High percentage agreement between raters was found (percentage agreement $=94 \%$ ).

\subsection{Self-Citations}

Using the "exclude self-citations" tool in Scopus, the percentage of self-citations within the list of 100 most highly cited articles derived from Scopus was calculated.

\subsection{Statistical Analysis}

The Pearson correlation coefficient $(r)$ was calculated to determine whether the number of years since publication was correlated with total number of citations among the included articles.

\subsection{Publication Trends}

Additional searches using the terms "psycho-oncology" and "psychosocial oncology" were conducted within Scopus. These searches and the resulting data provide a broad overview of the publication trends of articles using these terms.

\section{Results}

\subsection{Study Selection}

A PRISMA flow diagram for the Scopus results is provided in Figure 1. The initial search returned 197,569 results, of which the titles and abstracts of the 2000 highest-cited articles were screened using the eligibility criteria. Full-text screening was completed for 351 articles. Results were ranked according to citation counts to represent the 100 mostcited articles. A table of the included 100 publications and a citation details are presented in the Appendix A.

\subsection{Self-Citations}

Self-citations were found to represent 4.4 per cent of total citations retrieved from Scopus.

\subsection{Study Characteristics}

The characteristics of the articles retrieved are provided in Table 1. Of the 100 included papers, the highest-cited articles were published between 1992 and 2005. A significant correlation was found between years since publication and the number of citations $(p=0.039)$. The citation range was $488-8509$ (mean $=940.27, S D=1015.69)$. Similarly to recent bibliometric reviews $[22,39]$ a word cloud of the words contained in the titles of the 100 included studies was generated using wordle.net in order to depict influential prevailing words and 
themes within the field of psycho-oncology. Popular words and phrases are highlighted based on frequency and relevance to the titles of the 100 included papers (see Figure 2).

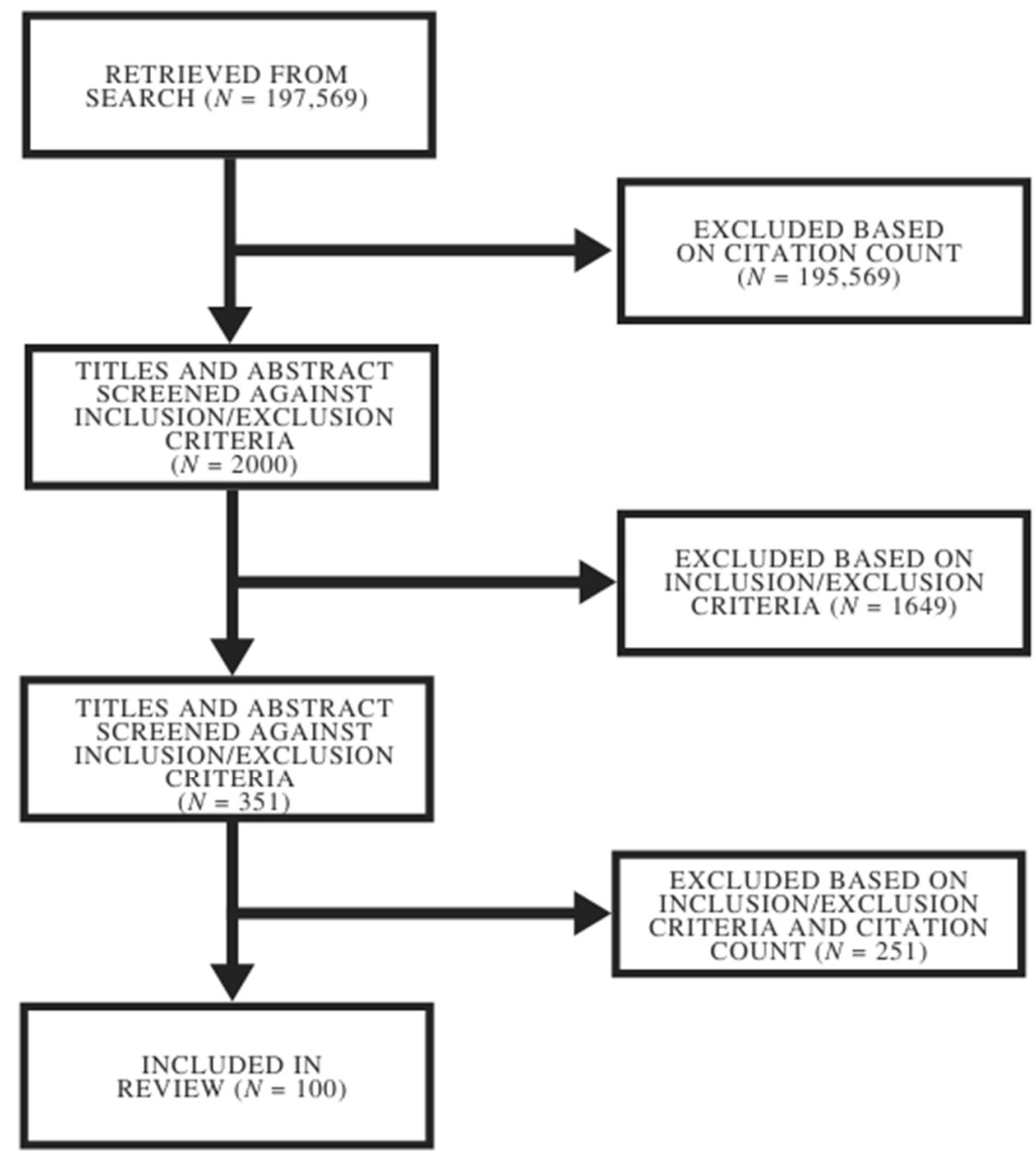

Figure 1. The PRISMA flowchart of study selection.

Table 1. Study characteristics of the top 100 published articles.

\begin{tabular}{cccc}
\hline Study Characteristics & Frequency \\
& $(\mathbf{\%})$ & Mean \pm SD & Citations \\
1. Country of Origin & & & \\
United States & 66 & $966.83 \pm 806.81$ & $491-4667$ \\
United Kingdom & 12 & $635 \pm 87.44$ & $518-801$ \\
Canada & 10 & $667 \pm 132.54$ & $512-909$ \\
The Netherlands & 4 & $2615.75 \pm 3954.77$ & $541-8547$ \\
Germany & 2 & $768.5 \pm 102.53$ & $696-841$ \\
Sweden & 2 & $627.5 \pm 75.66$ & $574-681$ \\
Australia & 1 & - & 1159 \\
Austria & 1 & - & 605 \\
Brazil & 1 & - & 723 \\
Denmark & 1 & - & 532 \\
Publication Type & & & $486-8451$ \\
Article & 80 & $925.23 \pm 992.84$ & $500-4565$ \\
Review paper & 18 & $1044.5 \pm 1184.88$ & $531-669$ \\
Conference paper & 2 & $600 \pm 97.58$ & \\
\hline
\end{tabular}


Table 1. Cont.

\begin{tabular}{|c|c|c|c|}
\hline \multirow[t]{2}{*}{ Study Characteristics } & \multirow{2}{*}{$\begin{array}{c}\text { Frequency } \\
(\%)\end{array}$} & \multicolumn{2}{|c|}{ Citations } \\
\hline & & Mean \pm SD & Range \\
\hline \multicolumn{4}{|l|}{ 3. Study Type } \\
\hline Tool development/evaluation & 21 & $1347.10 \pm 1811.02$ & $505-8451$ \\
\hline Observational (cross-sectional) & 20 & $782.05 \pm 287.63$ & $500-1369$ \\
\hline Observational (prospective cohort) & 17 & $716.35 \pm 303.22$ & $488-1549$ \\
\hline Review (non-systematic) & 12 & $1045.75 \pm 1168.71$ & $486-4565$ \\
\hline Intervention (RCT) & 11 & $906 \pm 970.03$ & $486-3824$ \\
\hline Intervention (non-RCT) & 10 & $903.5 \pm 407.36$ & $511-1782$ \\
\hline Review (systematic/meta-analysis) & 9 & $619.89 \pm 96.27$ & $507-767$ \\
\hline \multicolumn{4}{|l|}{ 4. Global Subject Topic } \\
\hline Psychological well-being & 14 & $758.93 \pm 371.98$ & $488-1862$ \\
\hline Quality of life & 14 & $1556 \pm 2142.43$ & $555-8451$ \\
\hline Psychological distress/Mental health & 12 & $892.33 \pm 446.91$ & $517-1782$ \\
\hline Patient-physician communication & 10 & $764.70 \pm 287.31$ & $507-1480$ \\
\hline Symptom prevalence & 10 & $672.80 \pm 181.95$ & 505-1079 \\
\hline Health promotion/Cancer prevention & 6 & $754.83 \pm 218.82$ & $486-1153$ \\
\hline Palliative/Supportive care & 6 & $1193.50 \pm 1295.41$ & $511-3824$ \\
\hline Psychoneuroimmunology & 6 & $570.83 \pm 79.56$ & $504-715$ \\
\hline Pain & 5 & $1220.40 \pm 944.66$ & 583-2885 \\
\hline Patient treatment choices & 4 & $573.75 \pm 73.89$ & $500-656$ \\
\hline Mindfulness & 2 & $2615 \pm 2757.72$ & $665-4565$ \\
\hline Psychological and physical health outcomes & 2 & $627.50 \pm 77.01$ & $573-682$ \\
\hline Survivorship & 2 & $696.50 \pm 221.32$ & $540-853$ \\
\hline Family/system outcomes & 1 & - & 566 \\
\hline \multicolumn{4}{|l|}{ 5. Cancer Type } \\
\hline Mixed cancer population & 36 & $907.33 \pm 832.36$ & $486-4565$ \\
\hline Breast & 25 & $757.08 \pm 369.68$ & $488-1862$ \\
\hline Advanced/terminal & 15 & $768.92 \pm 284.83$ & $511-1480$ \\
\hline Undefined & 13 & $890.15 \pm 621.50$ & $507-2885$ \\
\hline Prostate & 5 & $916.2 \pm 385.48$ & 571-1549 \\
\hline Lung & 2 & $6137.5 \pm 3271.78$ & $3824-8451$ \\
\hline Malignant melanoma & 2 & $682 \pm 241.83$ & $511-853$ \\
\hline Brain & 1 & - & 569 \\
\hline Cervical & 1 & - & 580 \\
\hline Gastric & 1 & - & 680 \\
\hline Laryngeal & 1 & - & 500 \\
\hline Colorectal & 1 & & 603 \\
\hline \multicolumn{4}{|l|}{ 6. Population } \\
\hline Adult & 97 & $944.14 \pm 1021.61$ & $486-8451$ \\
\hline Child & 3 & $653.33 \pm 133.13$ & $573-807$ \\
\hline
\end{tabular}

\subsection{The 100 Most-Cited Articles}

The distribution of results for the 100 most-cited articles is presented in Table 1. A comprehensive list of results is presented in the Appendix A.

\subsection{Country of Publication}

The country of origin of the first author for each article represented study origin data. Overall, 10 nations contributed to included study origin. The United States of America represented the largest contribution of studies $(66 \%)$, followed respectively by the United Kingdom (12\%) and Canada (10\%). See all contributory countries in Table 1, panel 1. 


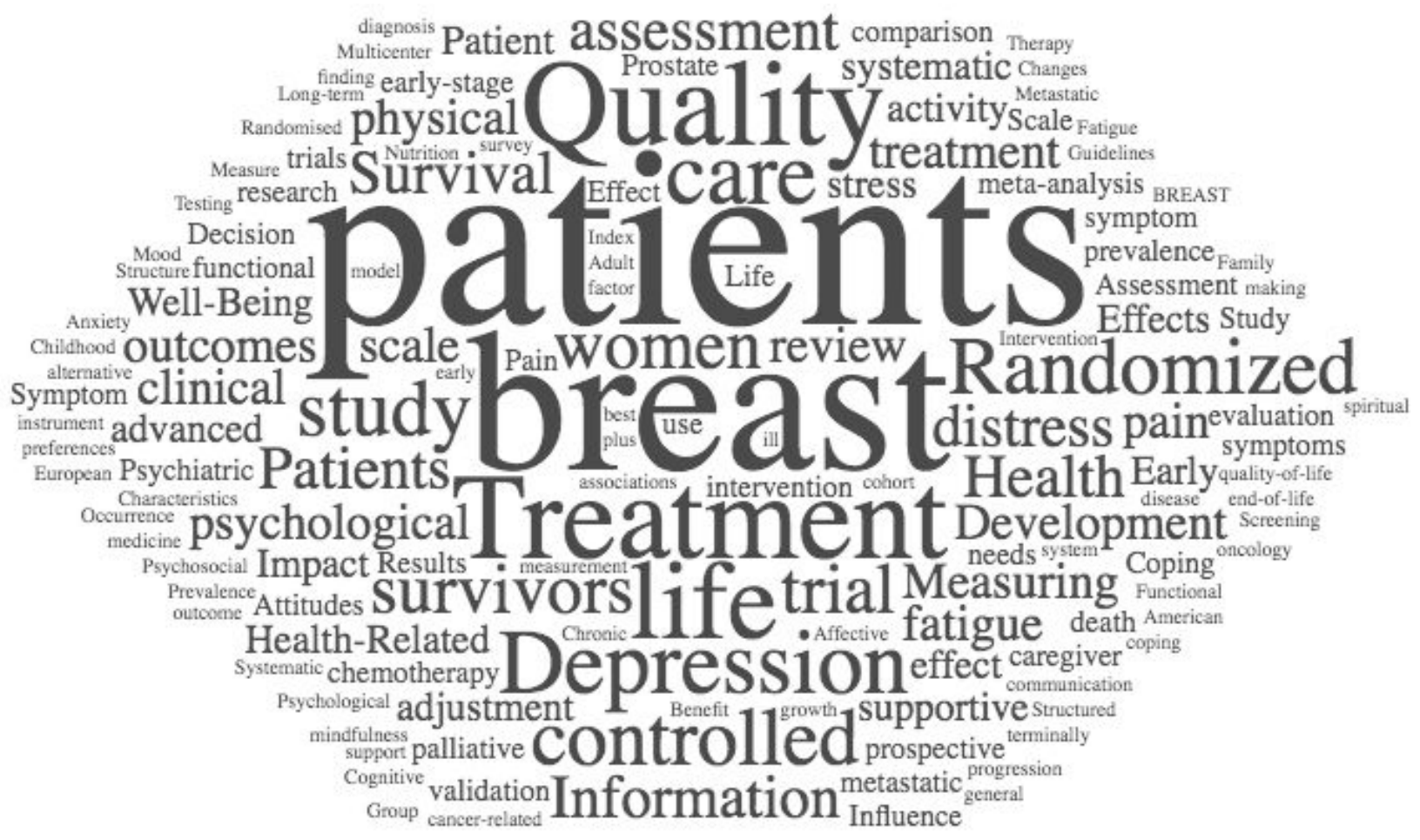

Figure 2. Word cloud of the words used in the titles of the 100 included studies.

\subsection{Publication Type}

The distribution of document type is presented in panel 2. Original articles represented $80 \%$ of the studies. Review papers and conference papers represented $18 \%$ and $2 \%$ of studies respectively.

\subsection{Type of Study}

Observational research study designs represented the majority of studies (37\%). Crosssectional observational designs represented the largest cohort of studies $(20 \%)$ followed closely by prospective designs (17\%). Tool development/evaluation, intervention and review studies each represented $21 \%$ of studies. Comprehensive distribution of study methodology is presented in panel 3 .

\subsection{Global Subject Topic}

Positive psychology represented the largest proportion of included studies (30\%), where the overarching global subject topic of studies examined psychological well-being and post-traumatic growth (14\%), quality of life $(14 \%)$, and mindfulness $(2 \%)$. Clinical psychology global topics represented the second-largest cohort of studies $(12 \%)$, where topics included psychological distress and mental health outcome including depression and suicidality were explored. Parallel psychological and physical health outcomes were the global subject topic for $2 \%$ of studies. Symptom prevalence represented $15 \%$ of study global subject topics, where $5 \%$ of studies examined pain prevalence and $10 \%$ explored additional cancer-related sequelae including the prevalence of cancer-related fatigue. Health promotion studies represented $6 \%$ of studies. These studies explored cancer prevention including self-monitoring behaviour, genomic testing, and survivorship intervention studies. Patient-physician communication and patient communication needs represented $10 \%$ of studies. Patient treatment choices including complementary and alternative medicine (CAM) represented $4 \%$ of studies. Palliative or supportive care studies represented $6 \%$. Psychoneuroimmunology research represented $6 \%$ of the studies. Survivorship analyses represented $6 \%$ of the studies. Family system outcomes represented $1 \%$ of studies. See panel 4 for comprehensive results. 


\subsection{Cancer Population}

The largest proportion of studies explored mixed cancer populations ( $36 \%$ ) followed by breast cancer populations ( $25 \%)$, and advanced/terminal cancer populations (15\%). A significant proportion of studies did not define the cancer population (13\%). A further $5 \%$ of studies included prostate cancer patients. Lung and malignant melanoma patients each represented $2 \%$ of studies. Brain, cervical, gastric, laryngeal, and colorectal cancer populations each represented $1 \%$ of studies. See panel 5 for comprehensive results. The vast majority of the included studies examined adult populations ( $97 \%)$. The remaining $3 \%$ of the studies examined child populations.

\subsection{Major Contributing Journals and Periods}

The 100 most-cited articles were published in 46 journals; 17 journals represented more than one study. The major contributing journals are presented in Table 2. The journals that contributed six or more of the 100 most-cited studies included the Journal of the American Medical Association, The New England Journal of Medicine, The Lancet, The British Medical Journal, Health Psychology and the Journal of Clinical Oncology. The journal that published the 100 most-cited psycho-oncology studies with the highest citation count was The Lancet.

Table 2. Journals that have published the highest-cited articles as listed in Scopus.

\begin{tabular}{ccccc}
\hline Journal & Frequency (\%) & $\begin{array}{c}\text { Sum } \\
\text { (No. Citations) }\end{array}$ & $\begin{array}{c}\text { Mean } \pm \text { SD } \\
\text { (No. Citations) }\end{array}$ & $\begin{array}{c}\text { Range } \\
\text { (No. Citations) }\end{array}$ \\
\hline Journal of the American & & 12,823 & $854.87 \pm 303.16$ & $507-1480$ \\
Medical Association & 15 & 9213 & $1151.63 \pm 1130.83$ & $500-3824$ \\
New England Journal of Medicine & 8 & 13,158 & $1879.71 \pm 2932.52$ & $511-8451$ \\
Lancet & 7 & 3773 & $628.83 \pm 54.09$ & $597-738$ \\
British Medical Journal & 6 & 3591 & $598.5 \pm 85.11$ & $500-695$ \\
Health Psychology & 6 & 7056 & $1176 \pm 1219.80$ & $540-3655$ \\
Journal of Clinical Oncology & 6 & 7038 & $1759.5 \pm 1891.73$ & $605-4565$ \\
Journal of Personality and & 4 & 2062 & $687.33 \pm 171.25$ & $511-853$ \\
Social Psychology & 3 & 2458 & $819.33 \pm 227.14$ & $583-1036$ \\
Archives of General Psychiatry & 3 & 1336 & $668 \pm 16.97$ & $656-680$ \\
Pain & 2 & 1088 & $544 \pm 26.87$ & $525-563$ \\
Annals of Oncology & 2 & 1247 & $623.5 \pm 81.32$ & $566-681$ \\
Archives of Internal Medicine & 2 & 1055 & $527.5 \pm 28.99$ & $507-548$ \\
Canadian Medical Association Journal & 2 & 1616 & $808 \pm 383.25$ & $537-1079$ \\
Cancer & 2 & 1284 & $642 \pm 103.24$ & $569-715$ \\
Journal of Pain and & 2 & 2166 & $1083 \pm 746.70$ & $555-1611$ \\
Symptom Management & 2 & 1200 & $600 \pm 97.58$ & $531-669$ \\
Lancet Oncology & 2 & 1188 & $594 \pm 152.74$ & $486-702$ \\
Psycho-Oncology & 2 & & & \\
Seminars in Haematology & & &
\end{tabular}

The 100 most-cited studies were published from 1975 to 2016. Figure 3 presents the publication trends for the 100 included publications. A period of 24 years represented $79 \%$ of studies, where the majority of studies were published between 1981-2005. A peak in publications was observed in the year 2000. 


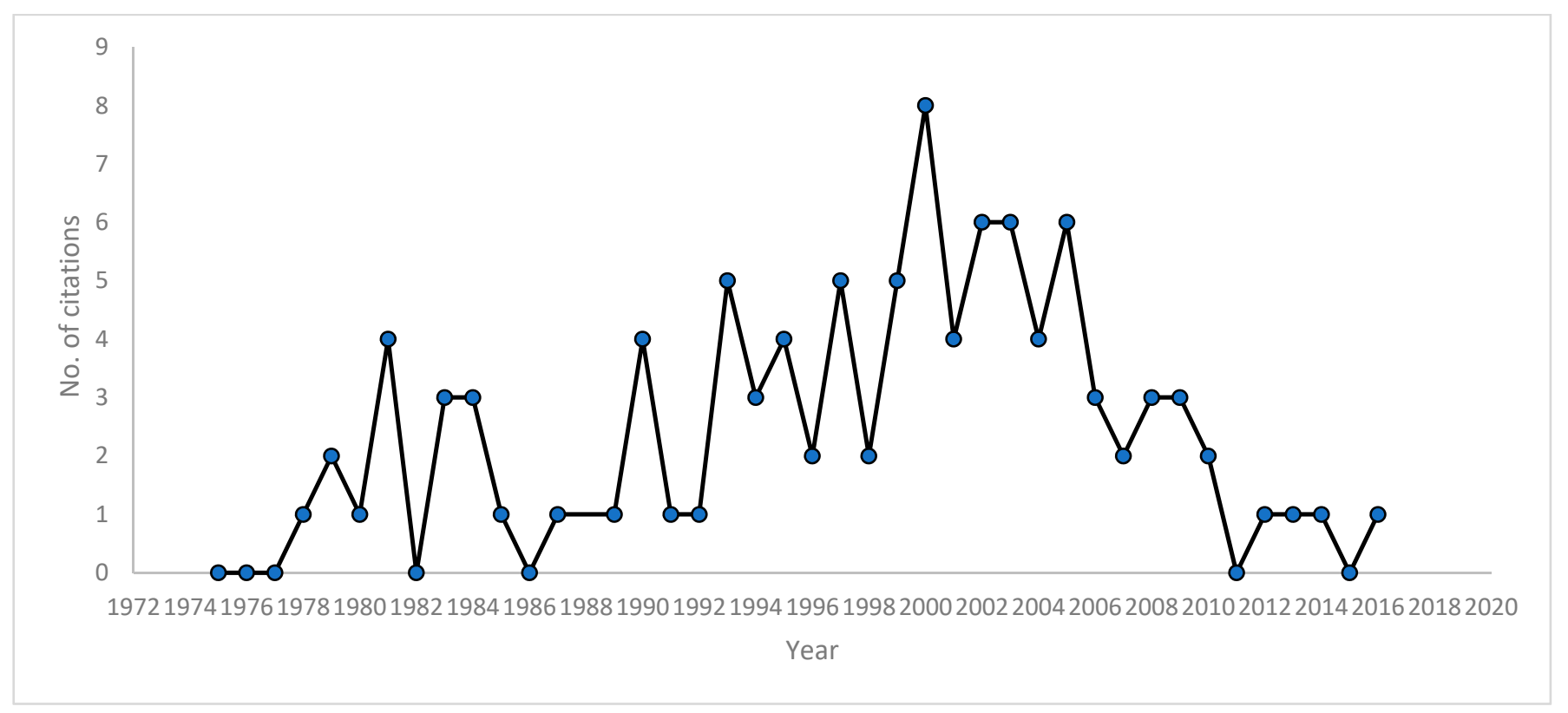

Figure 3. Publication trends for the 100 included publications.

Figure 4 provides an overview of publication trends within Scopus under the key terms "psycho oncology" and "psychosocial oncology". Publications under the term "psychosocial oncology" precede "psycho oncology" publications commencing in 1973. The term "psycho oncology" presents initially in 1979, demonstrating the evolution of the discipline. A peak in publications was observed in 2018 for both search terms.

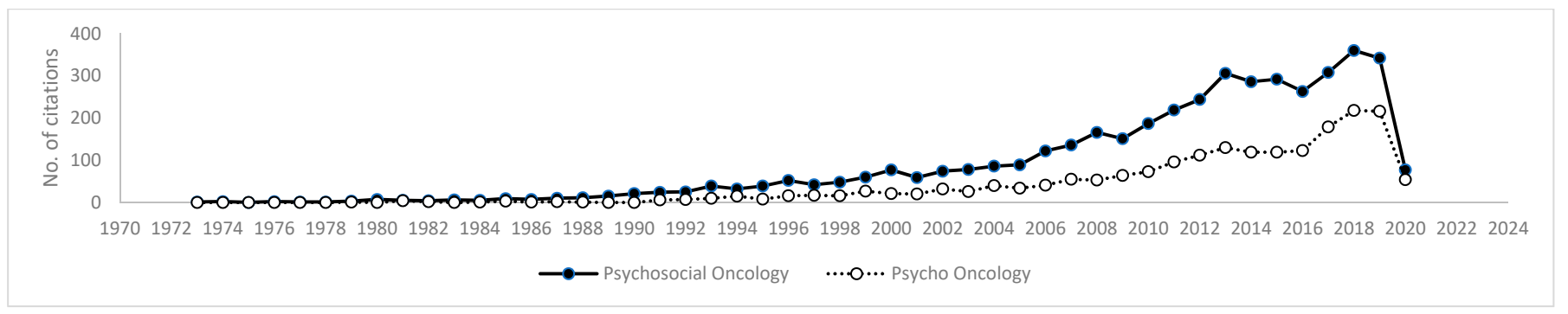

Figure 4. Publications by year for the terms "psychosocial oncology" and "psycho-oncology" in Scopus.

\subsection{The 10 Most-Cited Articles}

The ten most-cited studies are presented in Table 3. The articles included the following: three studies detailing the development and assessment of psychometric measures, two quality of life measures [40,41] and one pain measure [42]; two reviews, the first explores psychological adjustment to breast cancer diagnosis [43], and the latter explores the role of mindfulness in psychological well-being and includes a prospective mindfulness-based intervention for early-stage cancer patients [44]; one cross-sectional observational study which compares psychological distress prevalence by cancer site [45] two controlled trial studies, one randomised controlled trial exploring an early palliative care intervention for metastatic lung cancer patients [46]; and one prospective controlled trial exploring a psychosocial group-based intervention for metastatic breast cancer patients [47]; and finally two prospective cohort studies, one identifying the determinants of quality of life and satisfaction among prostate cancer survivors [48]; and one determining the impact of end-of-life patient-physician communication on patient mental health, medical care near death, and caregiver bereavement adjustment in advanced cancer patients and their family systems [49]. 
Table 3. The 10 highest-cited publications in psycho-oncology.

\begin{tabular}{|c|c|c|c|}
\hline Rank & Author and Year & Citations & Description \\
\hline 1 & Aaronson et al. 1993 & 8451 & $\begin{array}{c}\text { An assessment of the EORTC QLQ-C30 quality of life } \\
\text { psychometric tool. }\end{array}$ \\
\hline 2 & Brown and Ryan 2003 & 4565 & $\begin{array}{c}\text { An overview of the role of mindfulness in psychological } \\
\text { well-being and a prospective mindfulness-based intervention for } \\
\text { early-stage cancer patients. }\end{array}$ \\
\hline 3 & Temel et al. 2010 & 3824 & $\begin{array}{l}\text { An RCT where newly diagnosed patients with metastatic lung } \\
\text { cancer were randomised to receive either early palliative care } \\
\text { integrated with standard oncologic care/standard oncologic care. }\end{array}$ \\
\hline 4 & Cella et al. 1993 & 3655 & $\begin{array}{l}\text { The development and assessment of the FACT quality of life } \\
\text { psychometric tool. }\end{array}$ \\
\hline 5 & Cleeland and Ryan 1994 & 2885 & The development of the BPI pain psychometric tool. \\
\hline 6 & Taylor 1983 & 1862 & $\begin{array}{l}\text { A review of psychological adjustment to breast cancer diagnosis. } \\
\text { A prospective controlled trial where patients with metastatic }\end{array}$ \\
\hline 7 & Spiegel et al. 1989 & 1782 & $\begin{array}{c}\text { breast cancer were randomised to psychosocial group-based } \\
\text { intervention and standard oncologic care/standard } \\
\text { oncologic care. }\end{array}$ \\
\hline 8 & Zabora et al. 2001 & 1611 & $\begin{array}{l}\text { A cross-sectional observational study of psychological distress } \\
\text { prevalence and comparison by cancer site. }\end{array}$ \\
\hline 9 & Sanda et al. 2008 & 1549 & $\begin{array}{l}\text { A prospective cohort study identifying determinants of quality of } \\
\text { life and satisfaction among prostate cancer survivors. }\end{array}$ \\
\hline 10 & Wright et al. 2008 & 1480 & $\begin{array}{c}\text { A longitudinal prospective cohort study of patients with } \\
\text { advanced cancer and families to determine the impact of } \\
\text { end-of-life patient-physician communication on } \\
\text { patient/family outcomes. }\end{array}$ \\
\hline
\end{tabular}

\subsection{Major Contributing Authors}

Overall, a total of 158 authors contributed to the results. There was wide, disparate authorship for first authors where 91 first authors represented the 100 included studies. Of these included studies, only one first author had published three studies as first author [47,50,51]. Three other first authors each published two studies as first author [40,52-56]. Each of these authors contributed as co-authors to other studies indicating a psycho-oncological focus in their published work. Cella, D. contributed the largest number of studies to the research $(n=7)[40,52,57-61]$. Table 4 presents results for authors who contributed three or more of the 100 most-cited psycho-oncology articles.

Table 4. Authors who contributed three or more of the 100 most-cited psycho-oncology articles.

\begin{tabular}{ccccc}
\hline \multirow{2}{*}{ Author } & \multirow{2}{*}{ Total Articles $(n)$} & \multicolumn{2}{c}{ Role of Author in Total Articles } & \multirow{2}{*}{ Citation Count \pm SD } \\
\cline { 3 - 5 } & & First and Corresponding Author & Co-Author & \\
\hline Cella, D. & 7 & 2 & 5 & $1162.29 \pm 1115.27$ \\
Courneya, K.S. & 5 & 0 & 5 & $635.2 \pm 117.53$ \\
Breitbart, W. & 4 & 1 & 3 & $664.5 \pm 115.30$ \\
Litwin, M.S. & 4 & 2 & 2 & $1002.5 \pm 385.32$ \\
Portenoy, R.K. & 4 & 2 & 2 & $761.75 \pm 183.05$ \\
Demark-Wahnefried, W. & 3 & 1 & 2 & $642.67 \pm 137.00$ \\
Ganz, P.A. & 3 & 0 & 3 & $740.67 \pm 102.26$ \\
Greer, S. & 3 & 1 & 2 & $534 \pm 20.66$ \\
Sloan, J.A. & 3 & 0 & 3 & $747.67 \pm 173.62$ \\
Spiegel, D. & 3 & 3 & 0 & $994.67 \pm 688.72$ \\
\hline
\end{tabular}

\section{Discussion}

The aim of this review was to perform a bibliometric analysis of the 100 most-cited journal articles in psycho-oncology. It is, to the best of our knowledge, the first study to 
identify and describe the characteristics of highly cited journal articles and publication trends that have contributed to the development of the field.

The results of the bibliometric review provide a systematic overview of seminal research in psycho-oncology overtime. Our review presents a body of evidence which may have multiple applications for researchers and clinicians alike working in the field of psycho-oncology, including potential for the development of educational materials, journal editorial strategy, and future research.

In accordance with Scopus, our analysis revealed that the 100 most-cited articles were published between 1975 and 2016. This finding is in keeping with the timeline of previous reviews which describe the evolution of the discipline, from a time when a diagnosis of cancer was stigmatised and not openly disclosed to patients, and towards a time of more trauma-informed cancer care $[1,2,38]$. The 100 most-cited journal articles were all published by 2016 and the ten most-cited articles averaged 21.8 years since publication, indicating that the research exists along a developmental trajectory whereby time impacts on citation count and subsequent influence. The majority of research originated from the United States (66\%). The vast majority of research publications were original articles $(80 \%)$. Observational research study designs represented the majority of studies (37\%). Mixed cancer population research studies represented the largest cancer research population $(36 \%)$.

Our analysis revealed that positive psychology topics and clinical psychosocialoncology topics represented the most prolific proportion of included studies. This finding reflects one of the most fundamental questions that psycho-oncology seeks to understandhow do people with cancer feel? The global subject topics included in our analysis reflect the targets of previous narrative reviews of psycho-oncology [38]. Other subject topics included in our review explored parallel psychological and physical health outcomes, symptom prevalence including pain and cancer-related fatigue, health promotion and cancer prevention research including self-monitoring behaviour, genomic testing and survivorship intervention studies, patient-physician communication and patient communication needs, patient treatment choices including complementary and alternative medicine, palliative care research, psychoneuroimmunology, survivorship, and family system outcomes. Our analysis highlights the psychosocial transitory nature of cancer, which presents the potential for both positive and negative outcomes [62]. Findings reflect increased recognition for the "people part" of cancer care and the sixth vital sign in medicine-distress [63]. Enhanced patient participation and increased patient-physician communication in treatment decisions have been described in recent reviews of the field [3]. Beyond this, the analysis emphasises the impact of psychosocial factors in physical health and the growing attention that psychoneuroimmunology research has gained [64]. A paucity of highly cited research on adherance to cancer treatment was identified. Given the value of research on this subject topic for MDTs, this factor represents a deficit among included study topics.

Journal and author contributions were widely heterogeneous in nature. Our analyses revealed 91 first authors contributors across the 100 included studies. Notably, self-citations represented a very small percentage of citations (4.4\%). A previous review of self-citations in research indicated that self-citations typically account for an average $10-20 \%$ of citation counts [65]. The 100 included articles were published in 46 journals, where 17 journals represented more than one study. Included studies were published in high-impact factor journals. Our analysis of highly cited journal articles reflects the interdisciplinary nature of psychosocial-oncology, which demonstrated the interfacing and overlapping boundaries with general medicine, oncology, psychiatry, pain medicine, health, and social psychology [2]. In keeping with this finding, interdisciplinary researcher and Chair of the Interdisciplinary Department of Medical Social Sciences at Northwestern University, Prof. David Cella, was the most prolific author) [40,52,57-61]. Additional analysis of global publication trends within Scopus indicated that the term "psychosocial oncology" precedes "psycho-oncology". Although the percentage of publication increased over time, a noticeable peak in publications was observed in 2018 for both search terms, clearly demonstrating the dynamic evolution of the discipline. In addition to time, other secular trends such as 
increased capacity of search engines and access to research articles online positively impact citation count.

\subsection{Strengths and Limitations}

Beyond its novel contribution, this bibliometric analysis was strengthened by the use of two search methods. The keyword search enabled the identification of publication trends for psychosocial oncology in addition to psycho-oncology. This methodological consideration enriches the tapestry of the findings as psychosocial oncology terminology precedes psycho-oncology in the evolution of the field [1]. Additionally, the review was strengthened by its adherence to bibliometric technical methods $[66,67]$. A further strength of this study is the assessment of the prevalence of self-citations. Inclusion of this analyses explores academic biases which can artificially inflate citation impact rate by objectively assessing the impact of 'other-driven' citations [5,68]. Inversely, this bibliometric review is not without its own limitations. Specifically, a publication bias may have been induced by the methodological limitation to only include English language publications. This limitation may explain why the study origins of the leading contributing counties were Anglophonic countries, namely the USA, UK, and Canada, because seminal articles in other languages were not included.

Though comprehensive, our analysis was limited in that research influence was operationalised using a citation-driven approach. Indeed each metric has its own limitations that need to be considered when selecting an appropriate metric for evaluation. Given the advantages and disadvantages of citation counts, our analysis should be interpreted with caution $[5,68]$. In academia, it is a common misconception that citation counts provide a benchmark for the impact of research. It should be noted that citation-driven bibliometric analyses neglect to consider the influence of landmark conceptual research journal articles. Further, our analysis does not assess the quality of the research presented. Quality appraisal of the findings was not possible, given the heterogeneity of the resulting output. It is important to consider that citation count fails to represent the quality of the research. Our analysis cannot identify with any authority the key conceptual journal articles that have shaped the trajectory and development of the field. This shortcoming serves as a rationale to support the investigation of conceptually-driven influential psychosocial-oncology research in future. However, it can be noted that previous review articles have reflected on key conceptual developments [1,3]. Finally, the search was limited to the Scopus electronic database. While the inclusion of one electronic database is standard practice in bibliometric analyses $[14,16,17,30,31,33]$, it is important to critique any outcome metric provider. Key to database selection, Scopus provides tools for citation overview including self-citation analysis. However, highly cited articles in journals not indexed in Scopus may not have been captured in the findings. Further, citation count varies between databases $[5,68]$. For this reason, the ranking of included articles should be interpreted with caution.

\subsection{Implications for Psycho-Oncology Practice and Research}

Given the extensive remit of the multidisciplinary field of oncology, a bibliometric review of the psycho-oncology literature may prove a helpful introduction for multidisciplinary teams working in cancer care. This review offers a broad overview of seminal research in the field. It also honours the key contributors to the field by identifying work that has been frequently cited by other researchers. Clinicians new to the field may perceive psycho-oncology to solely encompass the psychological health of oncology patients. It is important to educate new clinicians to routinely and sensitively consider the individual and systemic level psychological, social, behavioural, and ethical aspects of cancer, since they can substantially influence the outcome of treatment. This review provides health professions with an educational resource that compounds our understanding of the mind-body interaction that continues to challenge a mechanical model of cancer.

This study generates knowledge regarding the intricacies of psycho-oncology clinical practice and research work and emphasises the need for compassionate collaborative, 
cross-disciplinary cancer care. It is important to acknowledge the need for translation beyond citation into interdisciplinary practice.

\subsection{Future Directions}

This bibliometric review provides a situational analysis of the field of psycho-oncology in the present, as opposed to a view of the future of the field. As discussed previously, it is important to note that our analyses offers a snapshot of highly cited seminal research in psycho-oncology at one point in time. Our analysis is best viewed as a live document responding to the evolving priorities of the field. We recommend replication studies at regular intervals to update the findings in order to maximise educational value. The nature of our review offers a broad scope of the field; future research could consider a more introspective bibliometric analysis of Psycho-Oncology exclusively [69]. Bibliometric reviews of single journals help chart the developmental growth and trajectory of a journal by identifying research trends, areas of research neglect, and disparities in academic publishing. Findings may offer editorial boards insight to help close gaps in research and help support funded external research grant calls [69].

Such an approach would offer increased insight and further support the maturity of the discipline, educational materials, and journal editorial strategy.

Relatively few high-quality RCT studies were included. This deficit identified in our analysis generates greater understanding of one of the pervading gaps in the research field. Our analysis underscores the critical need to enhance the science of psycho-oncology. Greater emphasis on high-quality methodological research is needed. This finding serves as a specific area of research opportunity to greater align future research to the needs of the field.

\section{Conclusions}

Psycho-oncology is a vast subspecialty of oncology encompassing diverse areas of clinical practice and research, focusing on the humanism in cancer-prevention, treatment, and aftercare. Given the evolution of the field from a place where the word 'cancer' was stigmatised and the feelings of cancer patients were not acknowledged, a bibliometric review which reflects on almost fifty years since the formal foundation of the field is overdue. This bibliometric review identifies the most frequently cited psycho-oncology journal articles published across all journals listed in Scopus. The results identified in this study are landmark papers that have contributed greatly to the field. This review denotes the growing nature of the discipline, which continues to advance. As the discipline has become increasingly established, there has been a simultaneous increase in research publications. While this study is not without its limitations, it is hoped that identification of seminal research publications will help inform future research contributions. This analysis should serve to support the routine consideration of the psychosocial aspects of cancer care. It may provide a useful educational tool for interdisciplinary clinicians. It is hoped that it will encourage considered compassionate care for cancer patients.

Supplementary Materials: The following are available online at https: / www.mdpi.com/article / 10.3390/healthcare9081008/s1: Supplementary Material 1. Scopus String Search, Supplementary Material 2. Preferred Reporting Items for Systematic reviews and Meta-Analyses extension for Scoping Reviews (PRISMA-ScR) Checklist.

Author Contributions: Conceptualization, S.F. and A.C.; methodology, S.F.; software, S.F.; validation, S.F., J.L., and P.D.; formal analysis, S.F. and A.C.; investigation, S.F.; resources, S.F.; data curation, S.F.; writing—original draft preparation, S.F.; writing—review and editing, S.F., J.L., P.D., A.C.; visualization, S.F.; supervision, A.C.; project administration, S.F.; funding acquisition, N/A. All authors have read and agreed to the published version of the manuscript.

Funding: This research received no external funding.

Institutional Review Board Statement: Not applicable. 
Informed Consent Statement: Not applicable.

Data Availability Statement: Data sharing is not applicable to this article as no new data were created or analysed in this study.

Conflicts of Interest: The authors declare no conflict of interest.

\section{Appendix A}

Table A1. Comprehensive results from Scopus for the 100 most cited journal articles.

\begin{tabular}{|c|c|c|c|c|}
\hline Rank & Authors & Title & Year & Journal \\
\hline 1 & Aaronson N.K., et al. [41] & $\begin{array}{l}\text { The European Organization For } \\
\text { Research And Treatment Of Cancer } \\
\text { QLQ-C30: A Quality-Of-Life } \\
\text { Instrument For Use In International } \\
\text { Clinical Trials In Oncology }\end{array}$ & 1993 & $\begin{array}{l}\text { Journal of the National } \\
\text { Cancer Institute }\end{array}$ \\
\hline 2 & Brown K.W., \& Ryan R.M. [44] & $\begin{array}{l}\text { The Benefits Of Being Present: } \\
\text { Mindfulness And Its Role In } \\
\text { Psychological Well-Being }\end{array}$ & 2003 & $\begin{array}{l}\text { Journal of Personality and } \\
\text { Social Psychology }\end{array}$ \\
\hline 3 & Temel J.S., et al. [46] & $\begin{array}{c}\text { Early Palliative Care For Patients } \\
\text { With Metastatic Non-Small-Cell } \\
\text { Lung Cancer }\end{array}$ & 2010 & $\begin{array}{l}\text { New England Journal } \\
\text { of Medicine }\end{array}$ \\
\hline 4 & Cella D.F., et al. [40] & $\begin{array}{c}\text { The Functional Assessment Of } \\
\text { Cancer Therapy Scale: Development } \\
\text { And Validation Of The } \\
\text { General Measure }\end{array}$ & 1993 & Journal of Clinical Oncology \\
\hline 5 & Cleeland C.S., et al. [42] & $\begin{array}{c}\text { Pain Assessment: Global Use Of The } \\
\text { Brief Pain Inventory. }\end{array}$ & 1994 & $\begin{array}{l}\text { Annals of the Academy of } \\
\text { Medicine, Singapore }\end{array}$ \\
\hline 6 & Taylor S.E. [43] & $\begin{array}{l}\text { Adjustment To Threatening Events: } \\
\text { A Theory Of Cognitive Adaptation } \\
\text { Effect Of Psychosocial Treatment On }\end{array}$ & 1983 & American Psychologist \\
\hline 7 & Spiegel D., et al. [47] & $\begin{array}{c}\text { Survival Of Patients With Metastatic } \\
\text { Breast Cancer }\end{array}$ & 1989 & The Lancet \\
\hline 8 & Zabora J., et al. [45] & $\begin{array}{c}\text { The Prevalence Of Psychological } \\
\text { Distress By Cancer Site }\end{array}$ & 2001 & Psycho-Oncology \\
\hline 9 & Sanda M.G., et al. [48] & $\begin{array}{l}\text { Quality Of Life And Satisfaction } \\
\text { With Outcome Among } \\
\text { Prostate-Cancer Survivors } \\
\text { Associations Between End-Of-Life }\end{array}$ & 2008 & $\begin{array}{l}\text { New England Journal } \\
\text { of Medicine }\end{array}$ \\
\hline 10 & Wright A.A., et al. [49] & $\begin{array}{l}\text { Discussions, Patient Mental Health, } \\
\text { Medical Care Near Death, And } \\
\text { Caregiver Bereavement Adjustment }\end{array}$ & 2008 & $\begin{array}{l}\text { Journal of the American } \\
\text { Medical Association }\end{array}$ \\
\hline 11 & Derogatis L.R., et al. [70] & $\begin{array}{l}\text { The Prevalence Of Psychiatric } \\
\text { Disorders Among Cancer Patients } \\
\text { How Coping Mediates The Effect Of }\end{array}$ & 1983 & $\begin{array}{l}\text { Journal of the American } \\
\text { Medical Association }\end{array}$ \\
\hline 12 & Carver C.S., et al. [71] & $\begin{array}{c}\text { Optimism On Distress: A Study Of } \\
\text { Women With Early Stage } \\
\text { Breast Cancer }\end{array}$ & 1993 & $\begin{array}{l}\text { Journal of Personality and } \\
\text { Social Psychology }\end{array}$ \\
\hline 13 & Spitzer W.O., et al. [72] & $\begin{array}{l}\text { Measuring The Quality Of Life Of } \\
\text { Cancer Patients. A Concise } \\
\text { QL-Index For Use By Physicians }\end{array}$ & 1981 & Journal of Chronic Diseases \\
\hline 14 & Holmes M.D., et al. [73] & $\begin{array}{c}\text { Physical Activity And Survival After } \\
\text { Breast Cancer Diagnosis }\end{array}$ & 2005 & $\begin{array}{l}\text { Journal of the American } \\
\text { Medical Association }\end{array}$ \\
\hline 15 & Murthy V.H., et al. [74] & $\begin{array}{c}\text { Participation In Cancer Clinical } \\
\text { Trials: Race-, Sex-, And } \\
\text { Age-Based Disparities }\end{array}$ & 2004 & $\begin{array}{l}\text { Journal of the American } \\
\text { Medical Association }\end{array}$ \\
\hline
\end{tabular}


Table A1. Cont.

\begin{tabular}{|c|c|c|c|c|}
\hline Rank & Authors & Title & Year & Journal \\
\hline 16 & Yellen S.B., et al. [61] & $\begin{array}{l}\text { Measuring Fatigue And Other } \\
\text { Anemia-Related Symptoms With } \\
\text { The Functional Assessment Of } \\
\text { Cancer Therapy (FACT) } \\
\text { Measurement System }\end{array}$ & 1997 & $\begin{array}{l}\text { Journal of Pain and } \\
\text { Symptom Management }\end{array}$ \\
\hline 17 & Serlin R.C., et al. [75] & $\begin{array}{c}\text { When Is Cancer Pain Mild, } \\
\text { Moderate Or Severe? Grading Pain } \\
\text { Severity By Its Interference } \\
\text { With Function }\end{array}$ & 1995 & Pain \\
\hline 18 & Portenoy R.K., et al. [55] & $\begin{array}{l}\text { The Memorial Symptom Assessment } \\
\text { Scale: An Instrument For The } \\
\text { Evaluation Of Symptom Prevalence, } \\
\text { Characteristics And Distress }\end{array}$ & 1994 & European Journal of Cancer \\
\hline 19 & Wei J.T., et al. [76] & $\begin{array}{l}\text { Development And Validation Of } \\
\text { The Expanded Prostate Cancer } \\
\text { Index Composite (EPIC) For } \\
\text { Comprehensive Assessment Of } \\
\text { Health-Related Quality Of Life In } \\
\text { Men With Prostate Cancer }\end{array}$ & 2000 & Urology \\
\hline 20 & Cassileth B.R., et al. [77] & $\begin{array}{l}\text { Information And Participation } \\
\text { Preferences Among Cancer Patients }\end{array}$ & 1980 & Annals of Internal Medicine \\
\hline 21 & Degner L.F., et al. [78] & $\begin{array}{l}\text { Information Needs And Decisional } \\
\text { Preferences In Women With } \\
\text { Breast Cancer }\end{array}$ & 1997 & $\begin{array}{l}\text { Journal of the American } \\
\text { Medical Association }\end{array}$ \\
\hline 22 & Bakitas M., et al. [79] & $\begin{array}{c}\text { Effects Of A Palliative Care } \\
\text { Intervention On Clinical Outcomes } \\
\text { In Patients With Advanced Cancer: } \\
\text { The Project ENABLE II Randomized } \\
\text { Controlled Trial } \\
\text { Measuring Spiritual Well-Being In }\end{array}$ & 2009 & $\begin{array}{l}\text { Journal of the American } \\
\text { Medical Association }\end{array}$ \\
\hline 23 & Peterman A.H., et al. [59] & $\begin{array}{c}\text { People With Cancer: The Functional } \\
\text { Assessment Of Chronic Illness } \\
\text { Therapy - Spiritual Well-Being Scale } \\
\text { (FACIT-Sp) }\end{array}$ & 2002 & $\begin{array}{c}\text { Annals of } \\
\text { Behavioral Medicine }\end{array}$ \\
\hline 24 & Litwin M.S., et al. [53] & $\begin{array}{l}\text { Quality-Of-Life Outcomes In Men } \\
\text { Treated For Localized } \\
\text { Prostate Cancer } \\
\text { Malignant Melanoma: Effects Of An }\end{array}$ & 1995 & $\begin{array}{l}\text { Journal of the American } \\
\text { Medical Association }\end{array}$ \\
\hline 25 & Fawzy F.I., et al. [80] & $\begin{array}{c}\text { Early Structured Psychiatric } \\
\text { Intervention, Coping, And Affective } \\
\text { State On Recurrence And Survival } 6 \\
\text { Years Later }\end{array}$ & 1993 & $\begin{array}{c}\text { Archives of } \\
\text { General Psychiatry }\end{array}$ \\
\hline 26 & Schipper H., et al. [81] & $\begin{array}{c}\text { Measuring The Quality Of Life Of } \\
\text { Cancer Patients: The Functional } \\
\text { Living Index-Cancer: Development } \\
\text { And Validation }\end{array}$ & 1984 & Journal of Clinical Oncology \\
\hline 27 & Zech D.F., et al. [82] & $\begin{array}{c}\text { Validation Of World Health } \\
\text { Organization Guidelines For Cancer } \\
\text { Pain Relief: A 10-Year } \\
\text { Prospective Study }\end{array}$ & 1995 & Pain \\
\hline 28 & Wolfe J., et al. [83] & $\begin{array}{l}\text { Symptoms And Suffering At The } \\
\text { End Of Life In Children With Cancer }\end{array}$ & 2000 & $\begin{array}{l}\text { New England Journal } \\
\text { of Medicine }\end{array}$ \\
\hline 29 & Shacham, S. [84] & $\begin{array}{l}\text { A Shortened Version Of The Profile } \\
\text { Of Mood States } \\
\text { Impact Of Cancer-Related Fatigue }\end{array}$ & 1983 & $\begin{array}{c}\text { Journal of } \\
\text { Personality Assessment }\end{array}$ \\
\hline 30 & Curt G.A., et al. [58] & $\begin{array}{l}\text { On The Lives Of Patients: New } \\
\text { Findings From The Fatigue Coalition }\end{array}$ & 2000 & Oncologist \\
\hline
\end{tabular}


Table A1. Cont.

\begin{tabular}{|c|c|c|c|c|}
\hline Rank & Authors & Title & Year & Journal \\
\hline 31 & Degner L.F., \& Sloan J.A. [85] & $\begin{array}{l}\text { Decision Making During Serious } \\
\text { Illness: What Role Do Patients } \\
\text { Really Want To Play? }\end{array}$ & 1992 & $\begin{array}{l}\text { Journal of Clinical } \\
\text { Epidemiology }\end{array}$ \\
\hline 32 & Speck R.M., et al. [86] & $\begin{array}{c}\text { An Update Of Controlled Physical } \\
\text { Activity Trials In Cancer Survivors: } \\
\text { A Systematic Review And } \\
\text { Meta-Analysis }\end{array}$ & 2010 & $\begin{array}{l}\text { Journal of Cancer } \\
\text { Survivorship }\end{array}$ \\
\hline 33 & Foley K.M. [87] & The Treatment Of Cancer Pain & 1985 & $\begin{array}{l}\text { New England Journal } \\
\text { of Medicine }\end{array}$ \\
\hline 34 & Demark-Wahnefried W., et al. [88] & $\begin{array}{l}\text { Riding The Crest Of The Teachable } \\
\text { Moment: Promoting Long-Term } \\
\text { Health After The Diagnosis } \\
\text { Of Cancer } \\
\text { Depression And Anxiety In Women }\end{array}$ & 2005 & Journal of Clinical Oncology \\
\hline 35 & Burgess C., et al. [89] & $\begin{array}{l}\text { Depression And Anxiety In Women } \\
\text { With Early Breast Cancer: Five Year } \\
\text { Observational Cohort Study }\end{array}$ & 2005 & British Medical Journal \\
\hline 36 & Calman K.C. [90] & $\begin{array}{l}\text { Quality Of Life In Cancer } \\
\text { Patients_An Hypothesis. }\end{array}$ & 1984 & Journal of Medical Ethics \\
\hline 37 & Bower J.E., et al. [91] & $\begin{array}{l}\text { Fatigue In Breast Cancer Survivors: } \\
\text { Occurrence, Correlates, And Impact } \\
\text { On Quality Of Life }\end{array}$ & 2000 & Journal of Clinical Oncology \\
\hline 38 & Reiche E.M.V., et al. [92] & $\begin{array}{l}\text { Stress, Depression, The Immune } \\
\text { System, And Cancer } \\
\text { Early Palliative Care For Patients }\end{array}$ & 2004 & Lancet Oncology \\
\hline 39 & Zimmermann C., et al. [93] & $\begin{array}{c}\text { With Advanced Cancer: A } \\
\text { Cluster-Randomised } \\
\text { Controlled Trial }\end{array}$ & 2014 & The Lancet \\
\hline 40 & Rock C.L., et al. [94] & $\begin{array}{l}\text { Nutrition And Physical Activity } \\
\text { Guidelines For Cancer Survivors }\end{array}$ & 2012 & $\begin{array}{l}\text { CA: Cancer Journal for } \\
\text { Clinicians }\end{array}$ \\
\hline 41 & Spiegel D., et al. [50] & $\begin{array}{l}\text { Group Support For Patients With } \\
\text { Metastatic Cancer: A Randomized } \\
\text { Prospective Outcome Study } \\
\text { Effects Of Psychosocial }\end{array}$ & 1981 & $\begin{array}{l}\text { Archives of General } \\
\text { Psychiatry }\end{array}$ \\
\hline 42 & Meyer T.J., \& Mark M.M. [95] & $\begin{array}{l}\text { Interventions With Adult Cancer } \\
\text { Patients: A Meta-Analysis Of } \\
\text { Randomized Experiments }\end{array}$ & 1995 & Health Psychology \\
\hline 43 & Breitbart W., et al. [96] & $\begin{array}{c}\text { Depression, Hopelessness, And } \\
\text { Desire For Hastened Death In } \\
\text { Terminally Ill Patients With Cancer } \\
\text { Cognitive-Behavioral Stress }\end{array}$ & 2000 & $\begin{array}{l}\text { Journal of the American } \\
\text { Medical Association }\end{array}$ \\
\hline 44 & Antoni M.H., et al. [97] & $\begin{array}{l}\text { Management Intervention Decreases } \\
\text { The Prevalence Of Depression And } \\
\text { Enhances Benefit Finding Among } \\
\text { Women Under Treatment For } \\
\text { Early-Stage Breast Cancer }\end{array}$ & 2001 & Health Psychology \\
\hline 45 & Detmar S.B., et al. [98] & $\begin{array}{l}\text { Assessments And Patient-Physician } \\
\text { Communication: A Randomized } \\
\text { Controlled Trial }\end{array}$ & 2002 & $\begin{array}{l}\text { Journal of the American } \\
\text { Medical Association }\end{array}$ \\
\hline 46 & De Haes M., et al. [99] & $\begin{array}{l}\text { Measuring Psychological And } \\
\text { Physical Distress In Cancer Patients: } \\
\text { Structure And Application Of The } \\
\text { Rotterdam Symptom Checklist }\end{array}$ & 1990 & British Journal of Cancer \\
\hline 47 & McNeely M.L., et al. [100] & $\begin{array}{c}\text { Effects Of Exercise On Breast Cancer } \\
\text { Patients And Survivors: A } \\
\text { Systematic Review And } \\
\text { Meta-Analysis }\end{array}$ & 2006 & $\begin{array}{l}\text { Canadian Medical } \\
\text { Association Journal }\end{array}$ \\
\hline
\end{tabular}


Table A1. Cont.

\begin{tabular}{|c|c|c|c|c|}
\hline Rank & Authors & Title & Year & Journal \\
\hline 48 & Glimelius B., et al. [101] & $\begin{array}{c}\text { Randomized Comparison Between } \\
\text { Chemotherapy Plus Best Supportive } \\
\text { Care With Best Supportive Care In } \\
\text { Advanced Gastric Cancer }\end{array}$ & 1997 & Annals of Oncology \\
\hline 49 & Goodwin P.J., et al. [102] & $\begin{array}{c}\text { The Effect Of Group Psychosocial } \\
\text { Support On Survival In Metastatic } \\
\text { Breast Cancer }\end{array}$ & 2001 & $\begin{array}{l}\text { New England Journal } \\
\text { of Medicine }\end{array}$ \\
\hline 50 & Lerman C., et al. [103] & $\begin{array}{l}\text { BRCA1 Testing In Families With } \\
\text { Hereditary Breast-Ovarian Cancer: } \\
\text { A Prospective Study Of Patient } \\
\text { Decision Making And Outcomes }\end{array}$ & 1996 & $\begin{array}{l}\text { Journal of the American } \\
\text { Medical Association }\end{array}$ \\
\hline 51 & Vogelzang N.J., et al. [60] & $\begin{array}{c}\text { Patient, Caregiver, And Oncologist } \\
\text { Perceptions Of Cancer-Related } \\
\text { Fatigue: Results Of A Tripart } \\
\text { Assessment Survey }\end{array}$ & 1997 & Seminars in Hematology \\
\hline 52 & Speca M., et al. [104] & $\begin{array}{l}\text { A Randomized, Wait-List Controlled } \\
\text { Clinical Trial: The Effect Of A } \\
\text { Mindfulness Meditation-Based } \\
\text { Stress Reduction Program On Mood } \\
\text { And Symptoms Of Stress In Cancer } \\
\text { Outpatients }\end{array}$ & 2000 & Psychosomatic Medicine \\
\hline 53 & Molassiotis A., et al. [105] & $\begin{array}{l}\text { Use Of Complementary And } \\
\text { Alternative Medicine In Cancer } \\
\text { Patients: A European Survey }\end{array}$ & 2005 & Annals of Oncology \\
\hline 54 & Litwin M.S., et al. [54] & $\begin{array}{l}\text { The UCLA Prostate Cancer Index: } \\
\text { Development, Reliability, And } \\
\text { Validity Of A Health-Related } \\
\text { Quality Of Life Measure }\end{array}$ & 1998 & Medical Care \\
\hline 55 & Taylor S.E., et al. [106] & $\begin{array}{l}\text { Attributions, Beliefs About Control, } \\
\text { And Adjustment To Breast Cancer } \\
\text { Efficacy Of A Cancer Research UK }\end{array}$ & 1984 & $\begin{array}{c}\text { Journal of Personality and } \\
\text { Social Psychology }\end{array}$ \\
\hline 56 & Fallowfield L., et al. [107] & $\begin{array}{l}\text { Communication Skills Training } \\
\text { Model For Oncologists: A } \\
\text { Randomised Controlled Trial }\end{array}$ & 2002 & Lancet \\
\hline 57 & Cordova M.J., et al. [62] & $\begin{array}{l}\text { Posttraumatic Growth Following } \\
\text { Breast Cancer: A Controlled } \\
\text { Comparison Study }\end{array}$ & 2001 & Health Psychology \\
\hline 58 & $\begin{array}{c}\text { Gomes B., \& } \\
\text { Higginson I.J. [108] }\end{array}$ & $\begin{array}{l}\text { Factors Influencing Death At Home } \\
\text { In Terminally Ill Patients With } \\
\text { Cancer: Systematic Review }\end{array}$ & 2006 & British Medical Journal \\
\hline 59 & Slevin M.L., et al. [109] & $\begin{array}{l}\text { Attitudes To Chemotherapy: } \\
\text { Comparing Views Of Patients With } \\
\text { Cancer With Those Of Doctors, } \\
\text { Nurses, And General Public }\end{array}$ & 1990 & British Medical Journal \\
\hline 60 & $\begin{array}{l}\text { Meyerowitz B.E., \& } \\
\text { Chaiken S. [110] }\end{array}$ & $\begin{array}{l}\text { The Effect Of Message Framing On } \\
\text { Breast Self-Examination Attitudes, } \\
\text { Intentions, And Behavior }\end{array}$ & 1987 & $\begin{array}{c}\text { Journal of Personality and } \\
\text { Social Psychology }\end{array}$ \\
\hline 61 & Scheithauer W., et al. [111] & $\begin{array}{l}\text { Randomised Comparison Of } \\
\text { Combination Chemotherapy Plus } \\
\text { Supportive Care With Supportive } \\
\text { Care Alone In Patients With } \\
\text { Metastatic Colorectal Cancer }\end{array}$ & 1993 & British Medical Journal \\
\hline 62 & Fallowfield L.J., et al. [112] & $\begin{array}{c}\text { Psychological Outcomes Of } \\
\text { Different Treatment Policies In } \\
\text { Women With Early Breast Cancer } \\
\text { Outside A Clinical Trial }\end{array}$ & 1990 & British Medical Journal \\
\hline
\end{tabular}


Table A1. Cont.

\begin{tabular}{|c|c|c|c|c|}
\hline Rank & Authors & Title & Year & Journal \\
\hline 63 & Rutten L.J.F., et al. [113] & $\begin{array}{l}\text { Information Needs And Sources Of } \\
\text { Information Among Cancer Patients: } \\
\text { A Systematic Review Of Research } \\
\qquad(1980-2003)\end{array}$ & 2005 & $\begin{array}{l}\text { Patient Education and } \\
\text { Counseling }\end{array}$ \\
\hline 64 & Leydon G.M., et al. [114] & $\begin{array}{l}\text { Cancer Patients' Information Needs } \\
\text { And Information Seeking Behaviour: } \\
\text { In Depth Interview Study }\end{array}$ & 2000 & British Medical Journal \\
\hline 65 & McCorkle R., \& Young K. [115] & $\begin{array}{c}\text { Development Of A Symptom } \\
\text { Distress Scale. }\end{array}$ & 1978 & Cancer Nursing \\
\hline 66 & Riley V. [116] & $\begin{array}{c}\text { Psychoneuroendocrine Influences } \\
\text { On Immunocompetence } \\
\text { And Neoplasia }\end{array}$ & 1981 & Science \\
\hline 67 & Portenoy R.K., et al. [56] & $\begin{array}{c}\text { Breakthrough Pain: Characteristics } \\
\text { And Impact In Patients With } \\
\text { Cancer Pain }\end{array}$ & 1999 & Pain \\
\hline 68 & $\begin{array}{c}\text { Brewer N.T., \& } \\
\text { Fazekas K.I. [117] }\end{array}$ & $\begin{array}{c}\text { Predictors Of HPV Vaccine } \\
\text { Acceptability: A Theory-Informed, } \\
\text { Systematic Review }\end{array}$ & 2007 & Preventive Medicine \\
\hline 69 & Kreuter M.W., et al. [118] & $\begin{array}{l}\text { Achieving Cultural Appropriateness } \\
\text { In Health Promotion Programs: } \\
\text { Targeted And Tailored Approaches } \\
\text { Chronic Psychological Stress And }\end{array}$ & 2003 & $\begin{array}{l}\text { Health Education } \\
\text { and Behavior }\end{array}$ \\
\hline 70 & Miller G.E., et al. [119] & $\begin{array}{c}\text { The Regulation Of Pro-Inflammatory } \\
\text { Cytokines: A } \\
\text { Glucocorticoid-Resistance Model }\end{array}$ & 2002 & Health Psychology \\
\hline 71 & Hudson M.M., et al. [120] & $\begin{array}{l}\text { Health Status Of Adult Long-Term } \\
\text { Survivors Of Childhood Cancer: A } \\
\text { Report From The Childhood Cancer } \\
\text { Survivor Study }\end{array}$ & 2003 & $\begin{array}{l}\text { Journal of the American } \\
\text { Medical Association }\end{array}$ \\
\hline 72 & Steineck G., et al. [121] & $\begin{array}{l}\text { Quality Of Life After Radical } \\
\text { Prostatectomy Or Watchful Waiting } \\
\text { Late Neurocognitive Sequelae In }\end{array}$ & 2002 & $\begin{array}{l}\text { New England Journal } \\
\text { of Medicine }\end{array}$ \\
\hline 73 & Mulhern R.K., et al. [122] & $\begin{array}{c}\text { Survivors Of Brain Tumours In } \\
\text { Childhood }\end{array}$ & 2004 & Lancet Oncology \\
\hline 74 & Grunfeld E., et al. [123] & $\begin{array}{c}\text { Family Caregiver Burden: Results } \\
\text { Of A Longitudinal Study Of Breast } \\
\text { Cancer Patients And Their Principal } \\
\text { Caregivers }\end{array}$ & 2004 & $\begin{array}{l}\text { Canadian Medical } \\
\text { Association Journal }\end{array}$ \\
\hline 75 & Ghezzi, P., et al. [124] & $\begin{array}{c}\text { Impact Of Follow-Up Testing On } \\
\text { Survival And Health-Related } \\
\text { Quality Of Life In Breast Cancer } \\
\text { Patients: A Multicenter Randomized } \\
\text { Controlled Trial }\end{array}$ & 1994 & $\begin{array}{l}\text { Journal of the American } \\
\text { Medical Association }\end{array}$ \\
\hline 76 & Zhang B., et al. [125] & $\begin{array}{c}\text { Health Care Costs In The Last Week } \\
\text { Of Life Associations With } \\
\text { End-Of-Life Conversations }\end{array}$ & 2009 & $\begin{array}{l}\text { Archives of Internal } \\
\text { Medicine }\end{array}$ \\
\hline 77 & Basch E., et al. [126] & $\begin{array}{l}\text { Symptom Monitoring With } \\
\text { Patient-Reported Outcomes During } \\
\text { Routine Cancer Treatment: A } \\
\text { Randomized Controlled Trial } \\
\text { Measurement Of Depressive }\end{array}$ & 2016 & Journal of Clinical Oncology \\
\hline 78 & Hann D., et al. [127] & $\begin{array}{c}\text { Symptoms In Cancer Patients: } \\
\text { Evaluation Of The Center For } \\
\text { Epidemiological Studies Depression } \\
\text { Scale (CES-D) }\end{array}$ & 1999 & $\begin{array}{c}\text { Journal of } \\
\text { Psychosomatic Research }\end{array}$ \\
\hline 79 & Greer S., et al. [128] & $\begin{array}{l}\text { Psychological Response To Breast } \\
\text { Cancer: Effect On Outcome }\end{array}$ & 1979 & The Lancet \\
\hline
\end{tabular}


Table A1. Cont.

\begin{tabular}{|c|c|c|c|c|}
\hline Rank & Authors & Title & Year & Journal \\
\hline 80 & Brady M.J., et al. [57] & $\begin{array}{l}\text { A Case For Including Spirituality In } \\
\text { Quality Of Life Measurement } \\
\text { In Oncology }\end{array}$ & 1999 & Psycho-Oncology \\
\hline 81 & Jacobsen P.B., et al. [129] & $\begin{array}{l}\text { Screening For Psychologic Distress } \\
\text { In Ambulatory Cancer Patients: A } \\
\text { Multicenter Evaluation Of The } \\
\text { Distress Thermometer }\end{array}$ & 2005 & Cancer \\
\hline 82 & Blanchard C.M., et al. [130] & $\begin{array}{l}\text { Cancer Survivors' Adherence To } \\
\text { Lifestyle Behavior } \\
\text { Recommendations And Associations } \\
\text { With Health-Related Quality Of Life: } \\
\text { Results From The American Cancer } \\
\text { Society's SCS-II }\end{array}$ & 2008 & Journal of Clinical Oncology \\
\hline 83 & Teunissen S., et al. [131] & $\begin{array}{l}\text { Symptom Prevalence In Patients } \\
\text { With Incurable Cancer: A } \\
\text { Systematic Review }\end{array}$ & 2007 & $\begin{array}{l}\text { Journal of Pain and } \\
\text { Symptom Management }\end{array}$ \\
\hline 84 & $\begin{array}{l}\text { Gøtzsche P.C., \& } \\
\text { Jørgensen K. [132] }\end{array}$ & $\begin{array}{l}\text { Screening For Breast Cancer With } \\
\text { Mammography } \\
\text { The Functional Assessment Of }\end{array}$ & 2013 & $\begin{array}{l}\text { Cochrane Database of } \\
\text { Systematic Reviews }\end{array}$ \\
\hline 85 & Cella, D. [52] & $\begin{array}{l}\text { Cancer Therapy-Anemia (FACT-An) } \\
\text { Scale: A New Tool For The } \\
\text { Assessment Of Outcomes In Cancer } \\
\text { Anemia And Fatigue }\end{array}$ & 1997 & Seminars in Hematology \\
\hline 86 & Watson M., et al. [133] & $\begin{array}{l}\text { Influence Of Psychological Response } \\
\text { On Survival In Breast Cancer: A } \\
\text { Population-Based Cohort Study } \\
\text { Occurrence, Causes, And Outcome }\end{array}$ & 1999 & Lancet \\
\hline 87 & Lawlor P.G., et al. [134] & $\begin{array}{c}\text { Of Delirium In Patients With } \\
\text { Advanced Cancer: A } \\
\text { Prospective Study }\end{array}$ & 2002 & $\begin{array}{l}\text { Archives of } \\
\text { Internal Medicine }\end{array}$ \\
\hline 88 & Burstein H.J., et al. [135] & $\begin{array}{c}\text { Use Of Alternative Medicine By } \\
\text { Women With Early-Stage } \\
\text { Breast Cancer }\end{array}$ & 1999 & $\begin{array}{l}\text { New England Journal } \\
\text { of Medicine }\end{array}$ \\
\hline 89 & Moorey S., et al. [136] & $\begin{array}{c}\text { The Factor Structure And Factor } \\
\text { Stability Of The Hospital Anxiety } \\
\text { And Depression Scale In Patients } \\
\text { With Cancer }\end{array}$ & 1991 & British Journal of Psychiatry \\
\hline 90 & McClain C.S., et al. [137] & $\begin{array}{l}\text { Effect Of Spiritual Well-Being On } \\
\text { End-Of-Life Despair In } \\
\text { Terminally-Ill Cancer Patients }\end{array}$ & 2003 & Lancet \\
\hline 91 & Fawzy F.I., et al. [138] & $\begin{array}{l}\text { A Structured Psychiatric } \\
\text { Intervention For Cancer Patients: I. } \\
\text { Changes Over Time In Methods Of } \\
\text { Coping And Affective Disturbance } \\
\text { Depression As A Predictor Of }\end{array}$ & 1990 & $\begin{array}{l}\text { Archives of General } \\
\text { Psychiatry }\end{array}$ \\
\hline 92 & Satin J.R., et al. [139] & $\begin{array}{l}\text { Disease Progression And Mortality } \\
\text { In Cancer Patients: A Meta-Analysis }\end{array}$ & 2009 & Cancer \\
\hline 93 & Novack D.H., et al. [140] & $\begin{array}{l}\text { Changes In Physicians' Attitudes } \\
\text { Toward Telling The Cancer Patient } \\
\text { The Yellow Brick Road And The } \\
\text { Emerald City: Benefit Finding, }\end{array}$ & 1979 & $\begin{array}{l}\text { Journal of the American } \\
\text { Medical Association }\end{array}$ \\
\hline 94 & Sears S.R., et al. [141] & $\begin{array}{l}\text { Positive Reappraisal Coping, And } \\
\text { Posttraumatic Growth In Women } \\
\text { With Early-Stage Breast Cancer } \\
\text { The Revised Piper Fatigue Scale: }\end{array}$ & 2003 & Health Psychology \\
\hline 95 & Piper B.F., et al. [142] & $\begin{array}{l}\text { Psychometric Evaluation In Women } \\
\text { With Breast Cancer. }\end{array}$ & 1998 & Oncology Nursing Forum \\
\hline 96 & $\begin{array}{c}\text { Spiegel D., \& } \\
\text { Giese-Davis J. [51] }\end{array}$ & $\begin{array}{c}\text { Depression And Cancer: } \\
\text { Mechanisms And Disease } \\
\text { Progression }\end{array}$ & 2003 & Biological Psychiatry \\
\hline
\end{tabular}


Table A1. Cont.

\begin{tabular}{|c|c|c|c|c|}
\hline Rank & Authors & Title & Year & Journal \\
\hline 97 & $\begin{array}{l}\text { Helgeson V.S., \& } \\
\text { Cohen S. [143] }\end{array}$ & $\begin{array}{l}\text { Social Support And Adjustment To } \\
\text { Cancer: Reconciling Descriptive, } \\
\text { Correlational, And } \\
\text { Intervention Research }\end{array}$ & 1996 & Health Psychology \\
\hline 98 & McNeil B.J., et al. [144] & $\begin{array}{c}\text { Speech And Survival: Tradeoffs } \\
\text { Between Quality And Quantity Of } \\
\text { Life In Laryngeal Cancer }\end{array}$ & 1981 & $\begin{array}{l}\text { New England Journal } \\
\text { of Medicine }\end{array}$ \\
\hline 99 & Stanton A.L., et al. [145] & $\begin{array}{l}\text { Emotionally Expressive Coping } \\
\text { Predicts Psychological And Physical } \\
\text { Adjustment To Breast Cancer }\end{array}$ & 2000 & $\begin{array}{l}\text { Journal of Consulting and } \\
\text { Clinical Psychology }\end{array}$ \\
\hline 100 & Doyle C., et al. [146] & $\begin{array}{c}\text { Nutrition And Physical Activity } \\
\text { During And After Cancer Treatment: } \\
\text { An American Cancer Society Guide } \\
\text { For Informed Choices }\end{array}$ & 2006 & $\begin{array}{l}\text { CA: Cancer Journal } \\
\text { for Clinicians }\end{array}$ \\
\hline
\end{tabular}

\section{References}

1. Holland, J.C. History of Psycho-Oncology: Overcoming Attitudinal and Conceptual Barriers. Psychosom. Med. 2002, 64, 206-221. [CrossRef]

2. Journal of Psychosocial Oncology, Journal of Psychosocial Oncology Aims \& Scope. Available online: https:/ / www.tandfonline. com/action/journalInformation?show=aimsScope\&journalCode=wjpo20 (accessed on 1 July 2021).

3. Holland, J.C. Psycho-Oncology: Overview, Obstacles and Opportunities. Psychooncology 2018, 27, 1364-1376. [CrossRef] [PubMed]

4. Greer, S. Psycho-oncology: Its Aims, Achievements and Future Tasks. Psycho-Oncology 1994, 3, 87-101. [CrossRef]

5. Agarwal, A.; Durairajanayagam, D.; Tatagari, S.; Esteves, S.C.; Harlev, A.; Henkel, R.; Roychoudhury, S.; Homa, S.; Puchalt, N.G.; Ramasamy, R.; et al. Bibliometrics: Tracking Research Impact by Selecting the Appropriate Metrics. Asian J. Androl. 2016, 18, 296-309. [CrossRef] [PubMed]

6. Bornmann, L.; Marx, W.; Gasparyan, A.Y.; Kitas, G.D. Diversity, Value and Limitations of the Journal Impact Factor and Alternative Metrics. Rheumatol. Int. 2012, 32, 1861-1867. [CrossRef]

7. Kanter, S.L. Understanding the Journal's Impact. Acad. Med. 2009, 84, 1169-1170. [CrossRef]

8. Lauer, M.S.; Danthi, N.S.; Kaltman, J.; Wu, C. Predicting Productivity Returns on Investment: Thirty Years of Peer Review, Grant Funding, and Publication of Highly Cited Papers at the National Heart, Lung, and Blood Institute. Circ. Res. 2015, 117, 239-243. [CrossRef]

9. Pritchard, A. Statistical Bibliography or Bibliometrics. J. Doc. 1969, 25, 348.

10. Saracevic, T.; Perk, L.J. Ascertaining Activities in a Subject Area through Bibliometric Analysis. Application to Library Literature. J. Am. Soc. Inf. Sci. 1973, 24, 120-134. [CrossRef]

11. Donohue, J.C. A Bibliometric Analysis of Certain Information Science Literature. J. Am. Soc. Inf. Sci. 1972, 23, 313-317. [CrossRef]

12. Campbell, D.; Picard-Aitken, M.; Côté, G.; Caruso, J.; Valentim, R.; Edmonds, S.; Williams, G.T.; Macaluso, B.; Robitaille, J.P.; Bastien, N.; et al. Bibliometrics as a Performance Measurement Tool for Research Evaluation: The Case of Research Funded by the National Cancer Institute of Canada. Am. J. Eval. 2010, 31, 66-83. [CrossRef]

13. Walsh, C.; Lydon, S.; Byrne, D.; Madden, C.; Fox, S.; O'Connor, P. The 100 Most Cited Articles on Healthcare Simulation: A Bibliometric Review. Simul. Healthc. 2018, 13, 211-220. [CrossRef]

14. Arul, K.; Mesfin, A. The Top 100 Cited Papers in Health Care Disparities: A Bibliometric Analysis. J. Racial Ethn. Heal. Disparities 2017, 4, 854-865. [CrossRef]

15. Kim, H.J.; Yoon, D.Y.; Kim, E.S.; Lee, K.; Bae, J.S.; Lee, J.H. The 100 most-cited articles in neuroimaging: A bibliometric analysis. NeuroImage 2016, 139, 149-156. [CrossRef]

16. Kim, Y.; Yoon, D.Y.; Kim, J.E.; Park, K.M.; Lee, J.H.; Song, H.K.; Bae, J.S. Citation Classics in Stroke: The Top-100 Cited Articles on Hemorrhagic Stroke. Eur. Neurol. 2017, 78, 210-216. [CrossRef] [PubMed]

17. Yeung, A.W.K.; Goto, T.K.; Leung, W.K. At the Leading Front of Neuroscience: A Bibliometric Study of the 100 Most-Cited Articles. Front. Hum. Neurosci. 2017, 11, 363. [CrossRef] [PubMed]

18. Yeung, A.W.K.; Goto, T.K.; Leung, W.K. Readability of the 100 Most-Cited Neuroimaging Papers Assessed by Common Readability Formulae. Front. Hum. Neurosci. 2018, 12, 308. [CrossRef]

19. Yeung, A.W.K. The 100 Most Cited Papers Concerning the Insular Cortex of the Brain: A Bibliometric Analysis. Front. Hum. Neurosci. 2018, 12, 337. [CrossRef] [PubMed]

20. Pan, Y.T.; Zhang, Y.H.; Gao, X.P.; Jia, J.; Gao, J.P.; Ma, Z. Scientific Progress Regarding Neural Regeneration in the Web of Science a 10-Year Bibliometric Analysis. Neural Regen. Res. 2013, 8, 3449-3454. [CrossRef] [PubMed]

21. Hoppen, N.H.F.; Vanz, S.A.d.S. Neurosciences in Brazil: A Bibliometric Study of Main Characteristics, Collaboration and Citations. Scientometrics 2016, 109, 121-141. [CrossRef] 
22. Dodier, O. A Bibliometric Analysis of the Recovered Memory Controversy in the 21st Century. Appl. Cogn. Psychol. 2019, 33, 571-584. [CrossRef]

23. Harrington, S.E.; Stout, N.L.; Hile, E.; Fisher, M.I.; Eden, M.; Marchese, V.; Pfalzer, L.A. Cancer Rehabilitation Publications (2008-2018) with a Focus on Physical Function: A Scoping Review. Phys. Ther. 2020, 100, 363-415. [CrossRef]

24. Stout, N.L.; Alfano, C.M.; Belter, C.W.; Nitkin, R.; Cernich, A.; Siegel, K.L.; Chan, L. A Bibliometric Analysis of the Landscape of Cancer Rehabilitation Research (1992-2016). J. Nat. Cancer Inst. 2018, 815-824. [CrossRef] [PubMed]

25. Wang, X.; Guo, J.; Gu, D.; Yang, Y.; Yang, X.; Zhu, K. Tracking Knowledge Evolution, Hotspots and Future Directions of Emerging Technologies in Cancers Research: A Bibliometrics Review. J. Cancer 2019, 10, 2643-2653. [CrossRef] [PubMed]

26. Wang, K.; Feng, C.; Li, M.; Pei, Q.; Li, Y.; Zhu, H.; Song, X.; Pei, H.; Tan, F. A Bibliometric Analysis of 23,492 Publications on Rectal Cancer by Machine Learning: Basic Medical Research Is Needed. Therap. Adv. Gastroenterol. 2020, 13, 175628482093459. [CrossRef] [PubMed]

27. Glynn, R.W.; Chin, J.Z.; Kerin, M.J.; Sweeney, K.J. Representation of Cancer in the Medical Literature-A Bibliometric Analysis. PLOS ONE 2010, 5, e13902. [CrossRef]

28. Kamdem, J.P.; Duarte, A.E.; Ibrahim, M.; Lukong, K.E.; Barros, L.M.; Roeder, T. Bibliometric Analysis of Personalized Humanized Mouse and Drosophila Models for Effective Combinational Therapy in Cancer Patients. Biochim. Biophys. Acta Mol. Basis Dis. 2020, 1866, 165880. [CrossRef] [PubMed]

29. Montazeri, A. Health-Related Quality of Life in Breast Cancer Patients: A Bibliographic Review of the Literature from 1974 to 2007. J. Exp. Clin. Cancer Res. 2008, 27, 1-31. [CrossRef] [PubMed]

30. Landreneau, J.P.; Weaver, M.; Delaney, C.P.; Aminian, A.; Dimick, J.B.; Lillemoe, K.D.; Schauer, P.R. The 100 Most Cited Papers in the History of the American Surgical Association. Ann. Surg. 2020, 271, 663-670. [CrossRef]

31. Müller, M.; Gloor, B.; Candinas, D.; Malinka, T. The 100 Most-Cited Articles in Visceral Surgery: A Systematic Review. Dig. Surg. 2016, 33, 509-519. [CrossRef]

32. Shuaib, W.; Acevedo, J.N.; Khan, M.S.; Santiago, L.J.; Gaeta, T.J. The Top 100 Cited Articles Published in Emergency Medicine Journals. Am. J. Emerg. Med. 2015, 33, 1066-1071. [CrossRef]

33. Nason, G.J.; Tareen, F.; Mortell, A. The Top 100 Cited Articles in Urology: An Update. J. Can. Urol. Assoc. 2013, 7. [CrossRef]

34. Web of Science. Web of Science Core Collection. Available online: https://clarivate.com/webofsciencegroup/solutions/web-ofscience-core-collection/ (accessed on 3 April 2020).

35. Cochrane Community. Covidence. Available online: https://community.cochrane.org/help/tools-and-software/covidence (accessed on 2 March 2020).

36. Kellermeyer, L.; Harnke, B.; Knight, S. Covidence and Rayyan. J. Med. Libr. Assoc. 2018, 106, 580. [CrossRef]

37. Macdonald, M.; Martin Misener, R.; Weeks, L.; Helwig, M. Covidence vs Excel for the Title and Abstract Review Stage of a Systematic Review. Int. J. Evid. Based. Healthc. 2016, 14, 200-201. [CrossRef]

38. Lang-Rollin, I.; Berberich, G. Psycho-Oncology. Dialogues Clin. Neurosci. 2018, 20, 13.

39. Plusquellec, P.; Denault, V. The 1000 Most Cited Papers on Visible Nonverbal Behavior: A Bibliometric Analysis. J. Nonverbal Behav. 2018, 42, 347-377. [CrossRef]

40. Cella, D.F.; Tulsky, D.S.; Gray, G.; Sarafian, B.; Linn, E.; Bonomi, A.; Silberman, M.; Yellen, S.B.; Winicour, P.; Brannon, J.; et al. The Functional Assessment of Cancer Therapy Scale: Development and Validation of the General Measure. J. Clin. Oncol. 1993, 11, 570-579. [CrossRef]

41. Aaronson, N.K.; Ahmedzai, S.; Bergman, B.; Bullinger, M.; Cull, A.; Duez, N.J.; Filiberti, A.; Flechtner, H.; Fleishman, S.B.; Haes, J.C.; et al. The European Organization for Research and Treatment of Cancer QLQ-C30: A Quality-of-Life Instrument for Use in International Clinical Trials in Oncology. J. Natl. Cancer Inst. 1993, 85, 365-376. [CrossRef] [PubMed]

42. Cleeland, C.S.; Ryan, K.M. Pain Assessment: Global Use of the Brief Pain Inventory. Ann. Acad. Med. Singapore 1994, 23, 129-138.

43. Taylor, S.E. Adjustment to Threatening Events: A Theory of Cognitive Adaptation. Am. Psychol. 1983, 38, 1161-1173. [CrossRef]

44. Brown, K.W.; Ryan, R.M. The Benefits of Being Present: Mindfulness and Its Role in Psychological Well-Being. J. Pers. Soc. Psychol. 2003, 84, 822-848. [CrossRef] [PubMed]

45. Zabora, J.; Brintzenhofeszoc, K.; Curbow, B.; Hooker, C.; Piantadosi, S. The Prevalence of Psychological Distress by Cancer Site. Psychooncology 2001, 10, 19-28. [CrossRef]

46. Temel, J.S.; Greer, J.A.; Muzikansky, A.; Gallagher, E.R.; Admane, S.; Jackson, V.A.; Dahlin, C.M.; Blinderman, C.D.; Jacobsen, J.; Pirl, W.F.; et al. Early Palliative Care for Patients with Metastatic Non-Small-Cell Lung Cancer. N. Engl. J. Med. 2010, 363, 733-742. [CrossRef]

47. Spiegel, D.; Kraemer, H.C.; Bloom, J.R.; Gottheil, E. Effect of Psychosocial Treatment on Survival of Patients with Metastatic Breast Cancer. Lancet 1989, 334, 888-891. [CrossRef]

48. Sanda, M.G.; Dunn, R.L.; Michalski, J.; Sandler, H.M.; Northouse, L.; Hembroff, L.; Lin, X.; Greenfield, T.K.; Litwin, M.S.; Saigal, C.S.; et al. Quality of Life and Satisfaction with Outcome among Prostate-Cancer Survivors. N. Engl. J. Med. 2008, 358, 1250-1261. [CrossRef] [PubMed]

49. Wright, A.A.; Zhang, B.; Ray, A.; Mack, J.W.; Trice, E.; Balboni, T.; Mitchell, S.L.; Jackson, V.A.; Block, S.D.; Maciejewski, P.K.; et al. Associations between End-of-Life Discussions, Patient Mental Health, Medical Care near Death, and Caregiver Bereavement Adjustment. JAMA J. Am. Med. Assoc. 2008, 300, 1665-1673. [CrossRef] 
50. Spiegel, D.; Bloom, J.R.; Yalom, I. Group Support for Patients with Metastatic Cancer: A Randomized Prospective Outcome Study. Arch. Gen. Psychiatry 1981, 38, 527-533. [CrossRef]

51. Spiegel, D.; Giese-Davis, J. Depression and cancer: Mechanisms and disease progression. Biol. Psychol. 2003, 54, $269-282$. [CrossRef]

52. Cella, D. The Functional Assessment of Cancer Therapy-Anemia (FACT-An) Scale: A New Tool for the Assessment of Outcomes in Cancer Anemia and Fatigue. Semin. Hematol. 1997, 34, 13-19.

53. Litwin, M.S.; Hays, R.D.; Fink, A.; Ganz, P.A.; Leake, B.; Leach, G.E.; Brook, R.H. Quality-of-Life Outcomes in Men Treated for Localized Prostate Cancer. JAMA J. Am. Med. Assoc. 1995, 273, 129-135. [CrossRef]

54. Litwin, M.S.; Hays, R.D.; Fink, A.; Ganz, P.A.; Leake, B.; Brook, R.H. The UCLA Prostate Cancer Index: Development, Reliability, and Validity of a Health-Related Quality of Life Measure. Med. Care 1998, 36, 1002-1012. [CrossRef] [PubMed]

55. Portenoy, R.K.; Thaler, H.T.; Kornblith, A.B.; McCarthy Lepore, J.; Friedlander-Klar, H.; Kiyasu, E.; Sobel, K.; Coyle, N.; Kemeny, N.; Norton, L.; et al. The Memorial Symptom Assessment Scale: An Instrument for the Evaluation of Symptom Prevalence, Characteristics and Distress. Eur. J. Cancer 1994, 30, 1326-1336. [CrossRef]

56. Portenoy, R.K.; Payne, D.; Jacobsen, P. Breakthrough Pain: Characteristics and Impact in Patients with Cancer Pain. Pain 1999, 81, 129-134. [CrossRef]

57. Brady, M.J.; Peterman, A.H.; Fitchett, G.; Mo, M.; Cella, D. A Case for Including Spirituality in Quality of Life Measurement in Oncology. Psychooncology. 1999, 8, 417-428. [CrossRef]

58. Curt, G.A.; Breitbart, W.; Cella, D.; Groopman, J.E.; Horning, S.J.; Itri, L.M.; Johnson, D.H.; Miaskowski, C.; Scherr, S.L.; Portenoy, R.K.; et al. Impact of Cancer-Related Fatigue on the Lives of Patients: New Findings From the Fatigue Coalition. Oncologist 2000, 5, 353-360. [CrossRef] [PubMed]

59. Peterman, A.H.; Fitchett, G.; Brady, M.J.; Hernandez, L.; Cella, D. Measuring Spiritual Well-Being in People with Cancer: The Functional Assessment of Chronic Illness Therapy—Spiritual Well-Being Scale (FACIT-Sp). Ann. Behav. Med. 2002, 24, 49-58. [CrossRef] [PubMed]

60. Vogelzang, N.J.; Breitbart, W.; Cella, D.; Curt, G.A.; Groopman, J.E.; Horning, S.J.; Itri, L.M.; Johnson, D.H.; Saherr, S.L.; Portenoy, R.K. Patient, Caregiver, and Oncologist Perceptions of Cancer-Related Fatigue: Results of a Tripart Assessment Survey. Semin. Hematol. 1997, 34, 4-12.

61. Yellen, S.B.; Cella, D.F.; Webster, K.; Blendowski, C.; Kaplan, E. Measuring Fatigue and Other Anemia-Related Symptoms with the Functional Assessment of Cancer Therapy (FACT) Measurement System. J. Pain Symptom Manage. 1997, 13, 63-74. [CrossRef]

62. Cordova, M.J.; Cunningham, L.L.C.; Carlson, C.R.; Andrykowski, M.A. Posttraumatic Growth Following Breast Cancer: A Controlled Comparison Study. Heal. Psychol. 2001, 20, 176-185. [CrossRef]

63. Holland, J.C.; Bultz, B.D. The NCCN Guideline for Distress Management: A Case for Making Distress the Sixth Vital Sign. J. Natl. Compr. Canc. Netw. 2007, 5, 3-7. [CrossRef]

64. Kiecolt-Glaser, J.K.; Robles, T.F.; Heffner, K.L.; Loving, T.J.; Glaser, R. Psycho-Oncology and Cancer: Psychoneuroimmunology and Cancer. Ann. Oncol. 2002, 13, 165-169. [CrossRef]

65. Hyland, K. Self-Citation and Self-Reference: Credibility and Promotion in Academic Publication. J. Am. Soc. Inf. Sci. Technol. 2003, 54, 251-259. [CrossRef]

66. Cronin, B. Bibliometrics and beyond: Some Thoughts on Web-Based Citation Analysis. J. Inf. Sci. 2001, 27, 1-7. [CrossRef]

67. Van Raan, A. The Use of Bibliometric Analysis in Research Performance Assessment and Monitoring of Interdisciplinary Scientific Developments. TATuP 2003, 12. [CrossRef]

68. Moustafa, K. Aberration of the Citation. Account. Res. 2016, 23, 230-244. [CrossRef]

69. Anyi, K.W.U.; Zainab, A.N.; Anuar, N.B. Bibliometric Studies on Single Journals: A Review. Malaysian J. Libr. Inf. Sci. 2009, 14, 17-55.

70. Derogatis, L.R.; Morrow, G.R.; Fetting, J.; Penman, D.; Piasetsky, S.; Schmale, A.M.; Henrichs, M.; Carnicke, C.L.M. The Prevalence of Psychiatric Disorders among Cancer Patients. JAMA J. Am. Med. Assoc. 1983, 249, 751-757. [CrossRef]

71. Carver, C.S.; Pozo, C.; Harris, S.D.; Noriega, V.; Scheier, M.F.; Robinson, D.S.; Ketcham, A.S.; Moffat, F.L.; Clark, K.C. How Coping Mediates the Effect of Optimism on Distress: A Study of Women With Early Stage Breast Cancer. J. Pers. Soc. Psychol. 1993, 65, 375-390. [CrossRef] [PubMed]

72. Spitzer, W.O.; Dobson, A.J.; Hall, J.; Chesterman, E.; Levi, J.; Shepherd, R.; Battista, R.N.; Catchlove, B.R. Measuring the Quality of Life of Cancer Patients. A Concise QL-Index for Use by Physicians. J. Chronic Dis. 1981, 34, 585-597. [CrossRef]

73. Holmes, M.D.; Chen, W.Y.; Feskanich, D.; Kroenke, C.H.; Colditz, G.A. Physical Activity and Survival after Breast Cancer Diagnosis. J. Am. Med. Assoc. 2005, 293, 2479-2486. [CrossRef]

74. Murthy, V.H.; Krumholz, H.M.; Gross, C.P. Participation in Cancer Clinical Trials: Race-, Sex-, and Age-Based Disparities. J. Am. Med. Assoc. 2004, 291, 2720-2726. [CrossRef] [PubMed]

75. Serlin, R.C.; Mendoza, T.R.; Nakamura, Y.; Edwards, K.R.; Cleeland, C.S. When Is Cancer Pain Mild, Moderate or Severe? Grading Pain Severity by Its Interference with Function. Pain 1995, 61, 277-284. [CrossRef]

76. Wei, J.T.; Dunn, R.L.; Litwin, M.S.; Sandler, H.M.; Sanda, M.G. Development and Validation of the Expanded Prostate Cancer Index Composite (EPIC) for Comprehensive Assessment of Health-Related Quality of Life in Men with Prostate Cancer. Urology 2000, 56, 899-905. [CrossRef] 
77. Cassileth, B.R.; Zupkis, R.V.; Sutton-Smith, K.; March, V. Information and Participation Preferences among Cancer Patients. Ann. Intern. Med. 1980, 92, 832-836. [CrossRef]

78. Degner, L.F.; Kristjanson, L.J.; Bowman, D.; Sloan, J.A.; Carriere, K.C.; O’Neil, J.; Bilodeau, B.; Watson, P.; Mueller, B. Information Needs and Decisional Preferences in Women with Breast Cancer. J. Am. Med. Assoc. 1997, 277, 1485-1492. [CrossRef]

79. Bakitas, M.; Lyons, K.D.; Hegel, M.T.; Balan, S.; Brokaw, F.C.; Seville, J.; Hull, J.G.; Li, Z.; Tosteson, T.D.; Byock, I.R.; et al. Effects of a Palliative Care Intervention on Clinical Outcomes in Patients with Advanced Cancer: The Project ENABLE II Randomized Controlled Trial. JAMA J. Am. Med. Assoc. 2009, 302, 741-749. [CrossRef]

80. Fawzy, F.I.; Fawzy, N.W.; Hyun, C.S.; Elashoff, R.; Guthrie, D.; Fahey, J.L.; Morton, D.L. Malignant Melanoma: Effects of an Early Structured Psychiatric Intervention, Coping, and Affective State on Recurrence and Survival 6 Years Later. Arch. Gen. Psychiatry 1993, 50, 681-689. [CrossRef]

81. Schipper, H.; Clinch, J.; McMurray, A.; Levitt, M. Measuring the Quality of Life of Cancer Patients: The Functional Living Index-Cancer: Development and Validation. J. Clin. Oncol. 1984, 2, 472-483. [CrossRef]

82. Zech, D.F.J.; Grond, S.; Lynch, J.; Hertel, D.; Lehmann, K.A. Validation of World Health Organization Guidelines for Cancer Pain Relief: A 10-Year Prospective Study. Pain 1995, 63, 65-76. [CrossRef]

83. Wolfe, J.; Grier, H.E.; Klar, N.; Levin, S.B.; Ellenbogen, J.M.; Salem-Schatz, S.; Emanuel, E.J.; Weeks, J.C. Symptoms and Suffering at the End of Life in Children with Cancer. N. Engl. J. Med. 2000, 342, 326-333. [CrossRef]

84. Shacham, S. A Shortened Version of the Profile of Mood States. J. Pers. Assess. 1983, 47, 305-306. [CrossRef]

85. Degner, L.F.; Sloan, J.A.J.A. Decision making during serious illness: What role do patients really want to play? J. Clin. Epidemiol. 1992, 45, 941-950. [CrossRef]

86. Speck, R.M.; Courneya, K.S.; Mâsse, L.C.; Duval, S.; Schmitz, K.H. An Update of Controlled Physical Activity Trials in Cancer Survivors: A Systematic Review and Meta-Analysis. J. Cancer Surviv. 2010, 4, 87-100. [CrossRef]

87. Foley, K.M. The Treatment of Cancer Pain. N. Engl. J. Med. 1985, 313, 84-95. [CrossRef]

88. Demark-Wahnefried, W.; Aziz, N.M.; Rowland, J.H.; Pinto, B.M. Riding the crest of the teachable moment: Promoting long-term health after the diagnosis of cancer. J. Clin. Oncol. 2005, 23, 5814-5830. [CrossRef]

89. Burgess, C.; Cornelius, V.; Love, S.; Graham, J.; Richards, M.; Ramirez, A. Depression and Anxiety in Women with Early Breast Cancer: Five Year Observational Cohort Study. Br. Med. J. 2005, 330, 702-705. [CrossRef] [PubMed]

90. Calman, K.C. Quality of Life in Cancer Patients-An Hypothesis. J. Med. Ethics 1984, 10, 124-127. [CrossRef]

91. Bower, J.E.; Ganz, P.A.; Desmond, K.A.; Rowland, J.H.; Meyerowitz, B.E.; Belin, T.R. Fatigue in Breast Cancer Survivors: Occurrence, Correlates, and Impact on Quality of Life. J. Clin. Oncol. 2000, 18, 743-753. [CrossRef] [PubMed]

92. Reiche, E.M.V.; Nunes, S.O.V.; Morimoto, H.K. Stress, Depression, the Immune System, and Cancer. Lancet Oncol. 2004, 5, 617-625. [CrossRef]

93. Zimmermann, C.; Swami, N.; Krzyzanowska, M.; Hannon, B.; Leighl, N.; Oza, A.; Moore, M.; Rydall, A.; Rodin, G.; Tannock, I.; et al. Early Palliative Care for Patients with Advanced Cancer: A Cluster-Randomised Controlled Trial. Lancet 2014, 383, 1721-1730. [CrossRef]

94. Rock, C.L.; Doyle, C.; Demark-Wahnefried, W.; Meyerhardt, J.; Courneya, K.S.; Schwartz, A.L.; Bandera, E.V.; Hamilton, K.K.; Grant, B.; McCullough, M.; et al. Nutrition and Physical Activity Guidelines for Cancer Survivors. CA Cancer J. Clin. 2012, 62, 242-274. [CrossRef] [PubMed]

95. Meyer, T.J.; Mark, M.M. Effects of Psychosocial Interventions with Adult Cancer Patients: A Meta-Analysis of Randomized Experiments. Heal. Psychol. 1995, 14, 101-108. [CrossRef]

96. Breitbart, W.; Rosenfeld, B.; Pessin, H.; Kaim, M.; Funesti-Esch, J.; Galietta, M.; Nelson, C.J.; Brescia, R. Depression, Hopelessness, and Desire for Hastened Death in Terminally Ill Patients with Cancer. J. Am. Med. Assoc. 2000, 284, 2907-2911. [CrossRef] [PubMed]

97. Antoni, M.H.; Lehman, J.M.; Kilbourn, K.M.; Boyers, A.E.; Culver, J.L.; Alferi, S.M.; Yount, S.E.; McGregor, B.A.; Arena, P.L.; Harris, S.D.; et al. Cognitive-Behavioral Stress Management Intervention Decreases the Prevalence of Depression and Enhances Benefit Finding among Women under Treatment for Early-Stage Breast Cancer. Health Psychol. 2001, 20, 20-32. [CrossRef]

98. Detmar, S.B.; Muller, M.J.; Schornagel, J.H.; Wever, L.D.V.; Aaronson, N.K. Health-Related Quality-of-Life Assessments and Patient-Physician Communication: A Randomized Controlled Trial. J. Am. Med. Assoc. 2002, 288, 3027-3034. [CrossRef]

99. De Haes, M.; Van Knippenberg, F.C.; Neijt, J.P. Measuring Psychological and Physical Distress in Cancer Patients: Structure and Application of the Rotterdam Symptom Checklist. Br. J. Cancer 1990, 62, 1034-1038. [CrossRef]

100. McNeely, M.L.; Campbell, K.L.; Rowe, B.H.; Klassen, T.P.; Mackey, J.R.; Courneya, K.S. Effects of exercise on breast cancer patients and survivors: A systematic review and meta-analysis. CMAJ 2006, 175, 34-41. [CrossRef]

101. Glimelius, B.; Ekström, K.; Hoffman, K.; Graf, W.; Sjödén, P.O.; Haglund, U.; Svensson, C.; Enander, L.K.; Linné, T.; Sellström, H.; et al. Randomized Comparison between Chemotherapy plus Best Supportive Care with Best Supportive Care in Advanced Gastric Cancer. Ann. Oncol. 1997, 8, 163-168. [CrossRef]

102. Goodwin, P.J.; Leszcz, M.; Ennis, M.; Koopmans, J.; Vincent, L.; Guther, H.; Drysdale, E.; Hundleby, M.; Chochinov, H.M.; Navarro, M.; et al. The Effect of Group Psychosocial Support on Survival in Metastatic Breast Cancer. N. Engl. J. Med. 2001, 345, 1719-1726. [CrossRef] 
103. Lerman, C.; Narod, S.; Schulman, K.; Hughes, C.; Gomez-Caminero, A.; Bonney, G.; Gold, K.; Trock, B.; Main, D.; Lynch, J.; et al. BRCA1 Testing in Families with Hereditary Breast-Ovarian Cancer: A Prospective Study of Patient Decision Making and Outcomes. J. Am. Med. Assoc. 1996, 275, 1885-1892. [CrossRef]

104. Speca, M.; Carlson, L.E.; Goodey, E.; Angen, M. A Randomized, Wait-List Controlled Clinical Trial: The Effect of a Mindfulness Meditation-Based Stress Reduction Program on Mood and Symptoms of Stress in Cancer Outpatients. Psychosom. Med. 2000, 62, 613-622. [CrossRef]

105. Molassiotis, A.; Fernandez-Ortega, P.; Pud, D.; Ozden, G.; Scott, J.A.; Panteli, V.; Margulies, A.; Browall, M.; Magri, M.; Selvekerova, S.; et al. Use of Complementary and Alternative Medicine in Cancer Patients: A European Survey. Ann. Oncol. 2005, 16, 655-663. [CrossRef]

106. Taylor, S.E.; Lichtman, R.R.; Wood, J.V. Attributions, Beliefs about Control, and Adjustment to Breast Cancer. J. Pers. Soc. Psychol. 1984, 46, 489-502. [CrossRef]

107. Fallowfield, L.; Jenkins, V.; Farewell, V.; Saul, J.; Duffy, A.; Eves, R. Efficacy of a Cancer Research UK Communication Skills Training Model for Oncologists: A Randomised Controlled Trial. Lancet 2002, 359, 650-656. [CrossRef]

108. Gomes, B.; Higginson, I.J. Factors Influencing Death at Home in Terminally Ill Patients with Cancer: Systematic Review. BMJ 2006, 332, 515-518. [CrossRef]

109. Slevin, M.L.; Stubbs, L.; Plant, H.J.; Wilson, P.; Gregory, W.M.; Armes, P.J.; Downer, S.M. Attitudes to Chemotherapy: Comparing Views of Patients with Cancer with Those of Doctors, Nurses, and General Public. Br. Med. J. 1990, 300, 1458-1460. [CrossRef]

110. Meyerowitz, B.E.; Chaiken, S. The Effect of Message Framing on Breast Self-Examination Attitudes, Intentions, and Behavior. J. Pers. Soc. Psychol. 1987, 52, 500-510. [CrossRef] [PubMed]

111. Scheithauer, W.; Rosen, H.; Kornek, G.V.; Sebesta, C.; Depisch, D. Randomised Comparison of Combination Chemotherapy plus Supportive Care with Supportive Care Alone in Patients with Metastatic Colorectal Cancer. Br. Med. J. 1993, 306, 752-755. [CrossRef] [PubMed]

112. Fallowfield, L.J.; Hall, A.; Maguire, G.P.; Baum, M. Psychological Outcomes of Different Treatment Policies in Women with Early Breast Cancer Outside a Clinical Trial. Br. Med. J. 1990, 301, 575-580. [CrossRef] [PubMed]

113. Rutten, L.J.; Arora, N.K.; Bakos, A.D.; Aziz, N.; Rowland, J. Information Needs and Sources of Information among Cancer Patients: A Systematic Review of Research (1980-2003). Patient Educ. Couns. 2005, 57, 250-261. [CrossRef]

114. Leydon, G.M.; Boulton, M.; Moynihan, C.; Jones, A.; Mossman, J.; Boudioni, M.; McPherson, K. Cancer Patients' Information Needs and Information Seeking Behaviour: In Depth Interview Study. Br. Med. J. 2000, 320, 909-913. [CrossRef]

115. McCorkle, R.; Young, K. Development of a Symptom Distress Scale. Cancer Nurs. 1978, 1, 373-378. [CrossRef] [PubMed]

116. Riley, V. Psychoneuroendocrine Influences on Immunocompetence and Neoplasia. Science 1981, 212, 1100-1109. [CrossRef] [PubMed]

117. Brewer, N.T.; Fazekas, K.I. Predictors of HPV Vaccine Acceptability: A Theory-Informed, Systematic Review. Prev. Med. 2007, 45, 107-114. [CrossRef]

118. Kreuter, M.W.; Lukwago, S.N.; Bucholtz, D.C.; Clark, E.M.; Sanders-Thompson, V. Achieving Cultural Appropriateness in Health Promotion Programs: Targeted and Tailored Approaches. Health Educ. Behav. 2003, 30, 133-146. [CrossRef] [PubMed]

119. Miller, G.E.; Cohen, S.; Ritchey, A.K. Chronic Psychological Stress and the Regulation of Pro-Inflammatory Cytokines: A Glucocorticoid-Resistance Model. Health Psychol. 2002, 21, 531-541. [CrossRef]

120. Hudson, M.M.; Mertens, A.C.; Yasui, Y.; Hobbie, W.; Chen, H.; Gurney, J.G.; Yeazel, M.; Recklitis, C.J.; Marina, N.; Robison, L.R.; et al. Health Status of Adult Long-Term Survivors of Childhood Cancer: A Report from the Childhood Cancer Survivor Study. J. Am. Med. Assoc. 2003, 290, 1583-1592. [CrossRef] [PubMed]

121. Steineck, G.; Helgesen, F.; Adolfsson, J.; Dickman, P.W.; Johansson, J.E.; Norlén, B.J.; Holmberg, L. Quality of Life after Radical Prostatectomy or Watchful Waiting. N. Engl. J. Med. 2002, 347, 790-796. [CrossRef]

122. Mulhern, R.K.; Merchant, T.E.; Gajjar, A.; Reddick, W.E.; Kun, L.E. Late Neurocognitive Sequelae in Survivors of Brain Tumours in Childhood. Lancet Oncol. 2004, 5, 399-408. [CrossRef]

123. Grunfeld, E.; Coyle, D.; Whelan, T.; Clinch, J.; Reyno, L.; Earle, C.C.; Willan, A.; Viola, R.; Coristine, M.; Janz, T.; et al. Family Caregiver Burden: Results of a Longitudinal Study of Breast Cancer Patients and Their Principal Caregivers. CMAJ 2004, 170, 1795-1801. [CrossRef]

124. Ghezzi, P.; Magnanini, S.; Rinaldini, M.; Berardi, F.; Di Biagio, G.; Testare, F.; Tavoni, N.; Schittulli, F.; D’Amico, C.; Pedicini, T.; et al. Impact of Follow-up Testing on Survival and Health-Related Quality of Life in Breast Cancer Patients: A Multicenter Randomized Controlled Trial. JAMA J. Am. Med. Assoc. 1994, 271, 1587-1592. [CrossRef]

125. Zhang, B.; Wright, A.A.; Huskamp, H.A.; Nilsson, M.E.; Maciejewski, M.L.; Earle, C.C.; Block, S.D.; Maciejewski, P.K.; Prigerson, H.G. Health Care Costs in the Last Week of Life Associations with End-of-Life Conversations. Arch. Intern. Med. 2009, 169, 480-488. [CrossRef]

126. Basch, E.; Deal, A.M.; Kris, M.G.; Scher, H.I.; Hudis, C.A.; Sabbatini, P.; Rogak, L.; Bennett, A.V.; Dueck, A.C.; Atkinson, T.M.; et al. Symptom Monitoring with Patient-Reported Outcomes during Routine Cancer Treatment: A Randomized Controlled Trial. J. Clin. Oncol. 2016, 34, 557-565. [CrossRef] [PubMed]

127. Hann, D.; Winter, K.; Jacobsen, P. Measurement of Depressive Symptoms in Cancer Patients: Evaluation of the Center for Epidemiological Studies Depression Scale (CES-D). J. Psychosom. Res. 1999, 46, 437-443. [CrossRef] 
128. Greer, S.; Morris, T.; Pettingale, K.W. Psychological Response to Breast Cancer: Effect on Outcome. Lancet 1979, $314,785-787$. [CrossRef]

129. Jacobsen, P.B.; Donovan, K.A.; Trask, P.C.; Fleishman, S.B.; Zabora, J.; Baker, F.; Holland, J.C. Screening for Psychologic Distress in Ambulatory Cancer Patients: A Multicenter Evaluation of the Distress Thermometer. Cancer 2005, 103, 1494-1502. [CrossRef] [PubMed]

130. Blanchard, C.M.; Courneya, K.S.; Stein, K. Cancer Survivors' Adherence to Lifestyle Behavior Recommendations and Associations with Health-Related Quality of Life: Results from the American Cancer Society's SCS-II. J. Clin. Oncol. 2008, 26, $2198-2204$. [CrossRef]

131. Teunissen, S.C.; Wesker, W.; Kruitwagen, C.; de Haes, H.C.; Voest, E.E.; de Graeff, A. Symptom Prevalence in Patients with Incurable Cancer: A Systematic Review. JPSM 2007, 34, 94-104. [CrossRef]

132. Gøtzsche, P.C.; Jørgensen, K.J. Screening for Breast Cancer with Mammography. Cochrane Database Syst. Rev 2013, 2013, CD001877. [CrossRef]

133. Watson, M.; Haviland, J.S.; Greer, S.; Davidson, J.; Bliss, J.M. Influence of Psychological Response on Survival in Breast Cancer: A Population-Based Cohort Study. Lancet 1999, 354, 1331-1336. [CrossRef]

134. Lawlor, P.G.; Gagnon, B.; Mancini, I.L.; Pereira, J.L.; Hanson, J.; Suarez-Almazor, M.E.; Bruera, E.D. Occurrence, Causes, and Outcome of Delirium in Patients with Advanced Cancer: A Prospective Study. Arch. Intern. Med. 2002, 160, 786-794. [CrossRef]

135. Burstein, H.J.; Gelber, S.; Guadagnoli, E.; Weeks, J.C. Use of Alternative Medicine by Women with Early-Stage Breast Cancer. N. Engl. J. Med. 1999, 340, 1733-1739. [CrossRef] [PubMed]

136. Moorey, S.; Greer, S.; Watson, M.; Gorman, C.; Rowden, L.; Tunmore, R.; Robertson, B.; Bliss, J. The Factor Structure and Factor Stability of the Hospital Anxiety and Depression Scale in Patients with Cancer. Br. J. Psychiatry 1991, 158, 255-259. [CrossRef]

137. McClain, C.S.; Rosenfeld, B.; Breitbart, W. Effect of Spiritual Well-Being on End-of-Life Despair in Terminally-Ill Cancer Patients. Lancet 2003, 361, 1603-1607. [CrossRef]

138. Fawzy, F.I.; Cousins, N.; Fawzy, N.W.; Kemeny, M.E.; Elashoff, R.; Morton, D. A Structured Psychiatric Intervention for Cancer Patients: I. Changes over Time in Methods of Coping and Affective Disturbance. Arch. Gen. Psychiatry 1990, 47, 720-725. [CrossRef]

139. Satin, J.R.; Linden, W.; Phillips, M.J. Depression as a Predictor of Disease Progression and Mortality in Cancer Patients: A Meta-Analysis. Cancer 2009, 115, 5349-5361. [CrossRef] [PubMed]

140. Novack, D.H.; Plumer, R.; Smith, R.L.; Morrow, G.R.; Ochitill, H.; Bennett, J.M. Changes in Physicians' Attitudes Toward Telling the Cancer Patient. JAMA J. Am. Med. Assoc. 1979, 241, 897-900. [CrossRef]

141. Sears, S.R.; Stanton, A.L.; Danoff-Burg, S. The Yellow Brick Road and the Emerald City: Benefit Finding, Positive Reappraisal Coping, and Posttraumatic Growth in Women with Early-Stage Breast Cancer. Health Psychol. 2003, 22, 487-497. [CrossRef]

142. Piper, B.F.; Dibble, S.L.; Dodd, M.J.; Weiss, M.C.; Slaughter, R.E.; Paul, S.M. The Revised Piper Fatigue Scale: Psychometric Evaluation in Women with Breast Cancer. Oncol. Nurs. Forum 1998, 25, 677-684. [PubMed]

143. Helgeson, V.S.; Cohen, S. Social Support and Adjustment to Cancer: Reconciling Descriptive, Correlational, and Intervention Research. Health Psychol. 1996, 15, 135-148. [CrossRef] [PubMed]

144. Mcneil, B.J.; Weichselbaum, R.; Pauker, S.G. Speech and Survival: Tradeoffs between Quality and Quantity of Life in Laryngeal Cancer. N. Engl. J. Med. 1981, 305, 982-987. [CrossRef] [PubMed]

145. Stanton, A.L.; Danoff-Burg, S.; Cameron, C.L.; Bishop, M.; Collins, C.A.; Kirk, S.B.; Sworowski, L.A.; Twillman, R. Emotionally Expressive Coping Predicts Psychological and Physical Adjustment to Breast Cancer. J. Consult. Clin. Psychol. 2000, 68, 875-882. [CrossRef] [PubMed]

146. Doyle, C.; Kushi, L.H.; Byers, T.; Courneya, K.S.; Demark-Wahnefried, W.; Grant, B.; McTiernan, A.; Rock, C.L.; Thompson, C.; Gansler, T.; et al. Nutrition and Physical Activity During and After Cancer Treatment: An American Cancer Society Guide for Informed Choices. CA Cancer J. Clin. 2006, 56, 323-353. [CrossRef] [PubMed] 